\title{
8. AZ ISKOLA ÖNFEJLESZTŐ TEVÉKENYSÉGE
}

\author{
SZÜCS IDA
}

\section{Bevezetés}

A 80-as, 90-es években az USA-ban dolgozták ki a szakmai fejlesztő iskolák (Professional Development School, PDS) koncepcióját, amelynek célja a pedagógusképzés színvonalának javítása és a lemorzsolódás csökkentése volt. Fennállásuk során a fejlődés négy szakaszát élték meg ezek az iskolák. Az első szakaszban az tanárképzéssel foglalkozó egyetemek kidolgozták magát a koncepciót. Később a koncepció fokozatosan a gyakorlóiskolák működésének központi szervezőelvévé vált. A fogalom teljesen újraértelmezte a tanárképző intézmények és a gyakorlóiskolák hagyományos kapcsolatát. A fejlődés második szakaszában kidolgozták a szakmai fejlesztő iskolák működésének szabályzóit, illetve létrehoztak egy, az iskolákat támogató rendszert. A harmadik szakaszban a figyelem egyre inkább a szakmai fejlesztő iskolák értékelésére irányult. A fó kérdés az lett, hogy mennyire segítik elő a tanulók és a hallgatók fejlődését, a pedagógusok és az oktatók szakmai fejlődését. A negyedik szakaszban az vált központi kérdéssé, hogy a szakmai fejlesztő iskolák mennyire tudnak megfelelni a tanulók eltérő igényeinek, mennyire tudják eredményesen kezelni az egyenlőtlenségeket (Teitel, 2004).

Jelenleg az Amerikai Egyesült Államokban működő Tanárképzés Nemzeti Akkreditációs Tanács (NCATE) a szakmai fejlesztő iskolák (PDS) számára a következő irányelveket tartja mérvadónak:

- A szakmai fejlesztő iskola (PDS) egy olyan tanulói közösség, amely egyszerre támogatja a tanulók fejlődését és a pedagógusok szakmai fejlödését.

- Elszámoltathatóság és minőségbiztosítás, azaz a szakmai fejlesztő iskola feladata olyan sztenderdek kidolgozása, amelyek biztosítják a tanulás és a tanítás magas színvonalát.

- Az iskola és a tanárképző intézmény együttműködése.

- Egyenlőség és különbözőség, azaz a szakmai fejlesztő iskola olyan szakembereket képez, akik képesek az eltérő igényekkel bíró tanulók felkészítésére.

- Olyan infrastruktúra létrehozása és fenntartása, amely biztosítja a magas színvonalú szakmai munka végzését.

A fenti irányelvek realizálásához a szakmai fejlesztő iskolának alkalmasnak kell lennie arra, hogy a hallgatók valódi képet kaphassanak az iskola kultúrájáról, jobban megérthessék 
a tanulók tanulási folyamatát, és széles körü tapasztalatokat szerezhessenek, amelyek révén könnyebb lesz számukra a beilleszkedés, amikor kezdő tanárként elhelyezkednek majd egy iskolában (NCATE, 2016)

Tanulmányunkban először is rövid szakirodalmi áttekintést kívánunk adni a szakmai fejlődés és fejlesztés fogalmáról és annak egyik szervezeti modelljéről, a szakmai fejlesztő iskoláról, majd ismertetni szeretnénk kutatási eredményeink alapján, hogy milyen nézeteket vallanak egy, a szakmai fejlesztő iskola megvalósításán dolgozó intézmény pedagógusai, az egyetem oktatói és hallgatói arra vonatkozóan, hogy a gyakorlóiskola milyen lehetőségeket biztosít számukra a folyamatos szakmai fejlődésükhöz, mennyiben javítják ezek a lehetőségek a szakmai munka hatékonyságát. Reméljük, eredményeink választ adnak arra a kiinduló kérdésre, hogy mitől jó egy gyakorlóiskola a szakmai önfejlesztés szempontjából.

\section{A pedagógusok szakmai fejlődése}

Mai világunkban a pedagógus szakma mint professzió, hivatás széles körben elfogadott, csakúgy, mint az orvosi, mérnöki vagy a jogászi szakmák. A társadalom elvárja, hogy e hivatásokat űző emberek magas színvonalon végezzék munkájukat, folyamatosan keressék a szakmai megújulás lehetőségeit, és éljenek is azokkal. Az élethosszig tartó tanulás a pedagógusok esetében is azt jelenti, hogy különböző fejlődési szakaszokat járnak be pályájuk során. Dreyfus és Dreyfus (1986) a fejlődési ciklusnak öt fázisát különíti el: a tanárképzős majd gyakornoki éveket követi a haladó-kezdő szakasz (2-3 éve pályán lévő pedagógusok), a kompetens szint (3-4 éve pályán lévők), a professzionális (5 éve pályán lévők), majd a szakértő szint. Bármelyik szakaszban is van a pedagógus, lépten-nyomon jelen van ezeken a szakaszokon belül maga a szakmai fejlődés. De mit is takar ez a fogalom? Szélesebb értelemben véve szakmai növekedés, fejlődés, amely a szakmai tapasztalatszerzés, valamint a saját szakmai tevékenység szisztematikus felülvizsgálata révén megy végbe (Glatthorn, 1995). Ez a fajta értelmezés megfelel a hagyományos felfogásnak, amely a pedagógusok továbbképzéseken, mühelyfoglalkozásokon való részvételét jelenti. Sok kritika érte ezt a felfogást többek között azért, mert nem igazán követi a pedagógusok valódi igényeit. A legújabb értelmezés szerint azonban a szakmai fejlődés hosszabb távú folyamat, amely magában foglalja a tényleges szakmai igényekhez igazodó, szisztematikusan megtervezett, rendszeresen előforduló lehetőségeket és tapasztalatokat, elősegítve ezzel a valódi szakmai fejlődést (Cochran-Smith és Lytle, 2001). A pedagógusok szakmai fejlődésének újfajta megközelítése a következő kritériumok mentén írható le:

- A konstruktivista tanulásfelfogás értelmezése szerint a pedagógus maga is aktív tanuló, aktív résztvevője a tanításnak, az értékelésnek, a megfigyelésnek és a reflektív tevékenységeknek (Darling-Hammond és McLaughlin, 1995). 
- A szakmai fejlődés hosszú távú folyamat, egymásra épülő szakmai tapasztalatok és visszacsatolások sorozataként valósul meg (Schifter, Russel és Bastable, 1999).

- A szakmai fejlődés kontextushoz kötött, vagyis konkrét osztálytermi munkához kapcsolódik (Wood és McQuarrie, 1999).

- Szorosan kapcsolódik az iskolai életében megvalósuló reformokhoz, ugyanis nem annyira képességfejlesztést, mint inkább szervezetikultúra-fejlesztést jelent (Schifter, Russel és Bastable, 1999).

- A pedagógus (Reflective practitioner) bizonyos tudással rendelkező, de azt állandóan felülvizsgáló és újabb pedagógiai elméleteket és gyakorlatot létrehozó egyénként áll a szakmai fejlődés középpontjában (Darling-Hammond és McLaughlin, 1995).

- A szakmai fejlődés együttműködésen alapul. Jelenti a pedagógusok egymás közötti, de a pedagógusok és szülők, pedagógusok és más szakmai szervezetek együttműködését (Grace, 1999) is.

- Bár a pedagógusok szakmai fejlődésének több modelljét is kidolgozták, mégis közös bennük, hogy a szakmai szükségleteket, az iskola struktúráját, szervezeti kultúráját, a pedagógusok hatékonyságának megítélését és motivációit mind figyelembe kell venni akkor, amikor valamelyik modell mellett letesszük a voksunkat. A szélesebb szakmai kontextus tehát mindig nagy fontossággal bír, amikor valamelyik modell kiválasztására kerül sor (Guskey, 1995).

A szakmai fejlődés jelentősége abban érhető tetten, hogy pozitív hatással van a tanárok nézeteire, hétköznapi gyakorlatára (Guskey, 1997), a diákok tanulására (Borko és Putnam, 1995), és nagyban elősegíti az oktatási reformok megvalósítását (Villegas-Reimers, Reimers, 1996, Little, 2001).

Kézenfekvő a következő kérdés: milyen tudással is kell rendelkeznie egy pedagógusnak? A pedagógus tudásának tartalma a következő: szaktárgyi tudás, pedagógiai tartalmi tudás (annak a tudása, hogyan kell tanítani a tantárgyi tartalmat), pedagógiai tudás (annak a tudása, hogyan kell tanítani általában). Gyakori az elméleti és gyakorlati tudás megkülönböztetése, amely arra utal, hogy a tanárok az elméleti ismeretek mellett saját tapasztalataik alapján is rendelkeznek tudással a tanításról, tanulásról. A tanár gyakorlati tudása több forrásból származik: egyéni tapasztalatok, másoktól készen átvett ismeretek és értékek (Falus, 2001). Ugyancsak a pedagógus tudásához tartozik a tanulók ismerete (Morales, 1998 idézi VillegasReimers, 2003), a tanulás eredményeinek értékelése, a tanulási környezet kialakításához és a közösség fejlesztéshez nélkülözhetetlen stratégiák és technikák ismerete, azon tudás és képességek összessége, amelyek lehetővé teszik a különböző kulturális és társadalmi hátterű tanulókkal való egyenlő bánásmódot (Gorski et al., 2000), és végül, de nem utolsó sorban bizonyos oktatástechnológiai ismeretek és készségek (Pianfetti, 2001) együttese. 
A pedagógusok szakmai fejlődésének elősegítésére több modellt is kidolgoztak. Ezek közül az egyik úgynevezett szervezeti együttműködési modell a szakmai fejlesztő iskola. Tanulmányunk bevezetésében, már említettük kialakulásának és fejlődésének körülményeit. A következőkben azokat a tulajdonságait emeljük ki, amelyek megkülönböztetik más, ugyancsak bizonyos szervezeti együttműködésen alapuló és a szakmai fejlesztést célul kitűző modellektől. Az első ilyen tulajdonság, hogy mind a pedagógusképző egyetem/ főiskola, mind pedig a szakmai gyakorlatot biztosító iskola szemléletbeli átalakulását jelenti a korábbi egyetem/fóiskola-gyakorlóiskola kapcsolathoz képest. A másik megkülönböztető jegy az, hogy mind az iskola, mind pedig a képző intézet oktatói egyenlő mértékben járulnak hozzá a szakmai együttműködéshez, a szakmai fejlődéshez. A harmadik nagyon fontos jellemzője a szakmai fejlesztő iskolának, hogy közös célokért folyik a munka. Ezek a közös célok a következők:

- felkészíteni a hallgatókat, majd a gyakornokokat a pedagógus hivatásra,

- javítani a pedagógusok munkakörülményeit,

- növelni a nevelés-oktatás színvonalát,

- megteremteni a pedagógusok és az iskolavezetők számára a magas színvonalú szakmai munka feltételeit (Darling-Hammond, 1994).

Mindezen feltételek új típusú szerepeket, feladatokat fogalmaznak meg a résztvevők számára. Ebben a típusú partneri együttműködésben gyakran előfordul, hogy a kutató lesz a tanár, vagy a tanár a kutató, az oktatók pedig hallgatókká válnak. Ahhoz, hogy a felsorolt kezdeti feltételek megvalósuljanak, új típusú feladatokat kell végrehajtaniuk az igazgatóknak, a tanároknak és természetesen az egyetemi oktatóknak. Az együttműködés a kulcsszó, amely az egymással való kapcsolatok tudatos alakítását, formálását vonja maga után. A tudatosság pedig szorosan kapcsolódik a tervszerűséghez. E három feltétel megléte biztosíthatja, hogy valódi kollegiális viszonyok között a résztvevők sokrétű innovatív tevékenységet folytassanak (Romerdahl és Gehrke, 1993; Kotschy, 2003).

E rövid elméleti bevezetőből is látható, hogy a szakmai fejlesztő iskola működését a tudatosság, a tervszerűség és az együttműködés hármas dimenziója mentén értelmezhetjük. A három fogalom a magas szintű professzionalitás alapját képezi. 


\section{Kutatás}

\section{Kutatásunk céljaiként a következőket fogalmaztuk meg:}

1. az iskolában dolgozó pedagógusok, gyakorló hallgatók és oktatók nézeteinek feltárását arra vonatkozóan, hogy az iskola milyen lehetőségeket biztosít számukra a folyamatos szakmai fejlődéshez, és hogy ezek a lehetőségek mennyiben javítják a szakmai munka hatékonyságát,

2. megválaszoljuk azt a kérdést, hogy mitől jó egy gyakorlóiskola a szakmai önfejlesztés szempontjából.

Ezen megfogalmazott kutatási célok azért bírnak fontossággal számunkra, hogy a mérőeszközökkel gyüjtött adatok és az azok elemzése során megfogalmazott követekeztetések egy tipikus gyakorlóiskola helyzetéről adjanak képet annak érdekében, hogy egy jövőben megvalósítandó szakmai fejlesztő iskola szisztematikus felépítéséhez tudományos megalapozottságal tudjunk javaslatokat megfogalmazni.

\section{Kutatásunk hipotézisei a következők:}

H1: A pedagógusok nézetei szerint az iskolavezetés nagy hangsúlyt helyez a pedagógusok szakmai tudásának tervszerű és tudatos fejlesztésre, mindez saját nézeteikben úgy tükröződik, hogy ők maguk is a magas szintű szakmai tudást tartják az iskola fejlődése szempontjából a legfontosabbnak.

H2: A gyakorlóiskolai pedagógusok saját szakmai tudásszintjének megítélése jelentős összefüggésben van a pedagógusok tudásmegosztásban való részvételének az arányával. H3: A gyakorlóiskola fejlesztő iskolává válásában a pedagógusok fontosnak tartják az egyetemmel közösen végzett kutatásokat, és ez a ténylegesen a kutatásokba bekapcsolódó pedagógusok számában is tükröződik.

H4: A gyakorlóiskolai pedagógusok magas szintủ szakmai tudása és a pálya iránti elkötelezettsége hat a hallgatók nézeteire.

H5: A pedagógusok törekszenek a tanárjelöltek bevonására az iskola szakmai önfejlesztő tevékenységébe elhivatottságuk növelése érdekében.

\section{Eredmények}

Kutatásunk eredményeinek bemutatásához először is ismertetjük azt a logikai vázat, amely mentén az adatok feldolgozása megtörtént. A szakmai fejlődés dimenzióit az iskolavezetés, 
a pedagógus, a tudásmegosztás, az egyetem és a gyakorlóiskola vonatkozásában írjuk le. Fontos, hogy ezen résztvevők nézeteit megismerjük a szakmaiság tekintetében. Természetesen minden érdekelt fél más és más miatt tartja fontosnak a szakmaiságot. Így kutatásunkkal rávilágíthatunk a nézőpontok eltérő voltára, és árnyaltabb tanulságokat fogalmazhatunk meg a jövőre vonatkozó elképzelésekkel kapcsolatban.

\subsection{A szakmai fejlődés dimenziói és az iskolavezetés}

E részterület esetében fontos kideríteni, hogy egyrészt a pedagógusok szerint a vezetés mennyire tudatosan tervezi meg az iskola szakmai fejlesztését, mik tartoznak a kiemelten fontos fejlesztendő területek közé. Másrészt, hogy a pedagógusok megítélése szerint mennyire tudatos az iskolavezetés a pedagógusok szakmai fejlesztése terén, a pedagógusok egyáltalán érzik-e az iskolavezetés tudatosságát ezen a területen (Tudomása szerint létezik-e az iskolának hosszabb távú [legalább 3 éves] továbbképzési terve? ... igen, tudomásom szerint van, ... nem, tudomásom szerint nincs, ... nem tudok róla). A pedagógusok többsége (69\%) tudatában van annak, hogy az iskolának hosszabb távú (legalább 3 éves) továbbképzési terve van. 3\%-uk szerint ilyen nincs, és $28 \%$ nem tud róla.

Mindebből következik az a kérdés, a pedagógusok szerint az iskolavezetés milyen területeket tart a szakmai fejlődés vonatkozásában a legfontosabbnak (Véleménye szerint az iskola mely területeken tartja a legfontosabbnak a pedagógusi szakmai fejlödését? Megadott kategóriákból a három legfontosabb jelölése).

Az 1. táblázatból (lásd Melléklet) látható, hogy a pedagógusok a legmagasabb átlagértéket a vezetés által leginkább preferált szakmai területek közül a módszertani tudásra (átlag = 0,52), az IKT-kompetencia fejlesztésére (átlag =0,50) és a tehetséggondozás fejlesztésére (átlag = 0,47) adták. Az összes megjelölt kategória rangsorában a módszertani fejlesztés az első, az IKT-kompetencia a negyedik, a szakmai előmenetel pedig a hatodik helyen került megnevezésre. A reflektív tanítás fejlesztését és a helyi kutatásokra való felkészítést a 17 kategóriából a tizenharmadik helyre sorolták a pedagógusok.

Az iskolavezetés által fontosnak tartott szakmai fejlesztési területeket összehasonlítottuk a pedagógusok fejlesztési igényeivel és a megvalósult továbbképzések tartalmával (Véleménye szerint az iskola mely területeken tartja a legfontosabbnak a pedagógusi szakmai fejlödését? Megadott kategóriákból három legfontosabb jelölése; Jelenleg mely területeken tartja a leginkább szükségesnek a saját szakmai fejlödését? ... Több választ is megjelölhet és a továbbképzéseket összesítő dokumentum). 


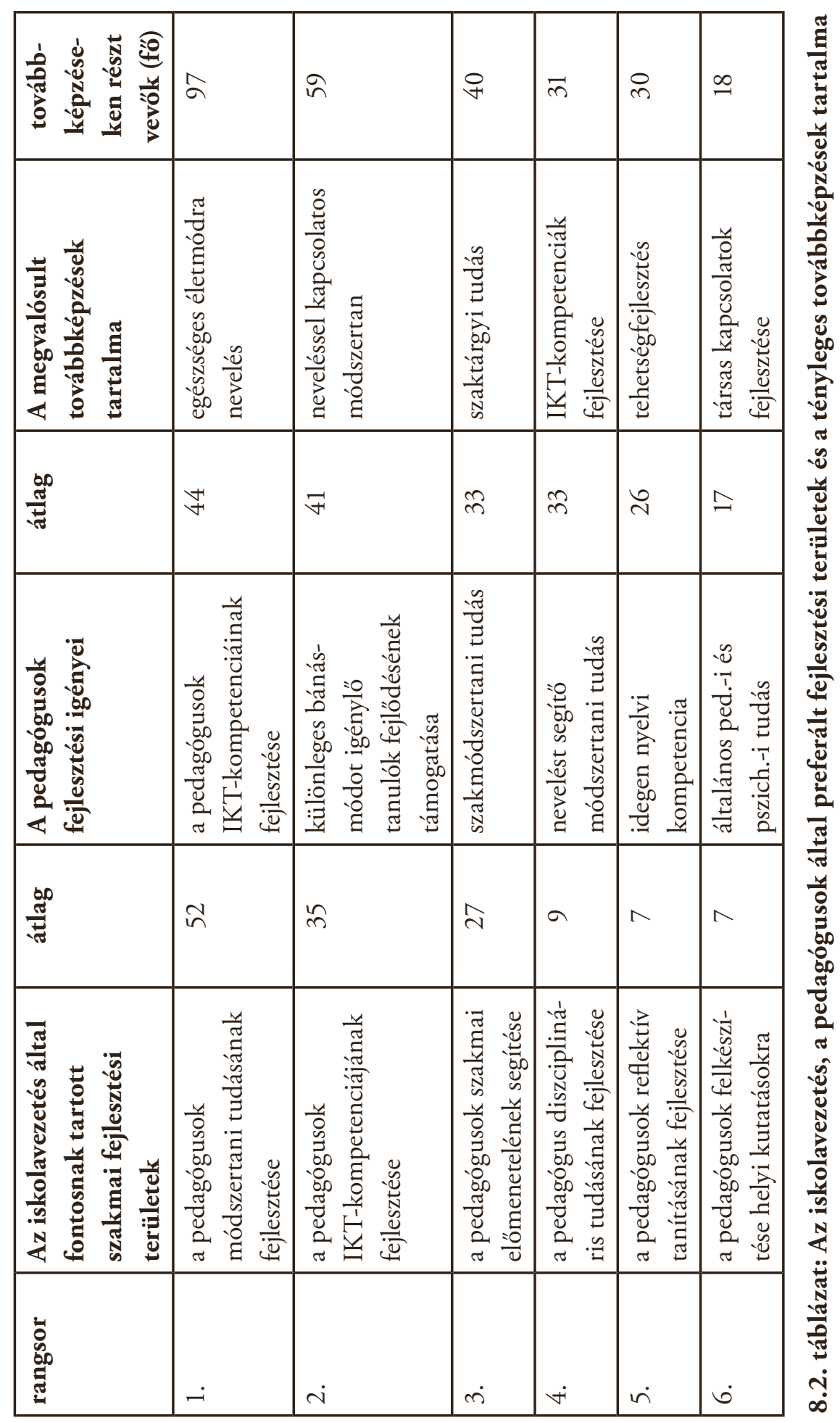


A 2. táblázat adataiból jól látható, hogy az iskolavezetés és a pedagógusok prioritásai csak részben fedik le egymást. Igaz, az első három helyen található mindkét csoportnál a pedagógusok módszertani és IKT-kompetenciáinak fejlesztése, az iskolavezetésnél azonban hangsúlyosabban jelenik meg a pedagógusok szakmai előmenetelének támogatása vagy az ötödik és hatodik helyen megnevezett reflektivitás fejlesztése és a helyi kutatásokra való felkészítés, ezzel szélesebb spektrumot adva az iskola és a pedagógusok szakmai fejlődésének. A pedagógusoknál a módszertan a legfontosabb fejlesztési igény, legyen szó szakmódszertanról, a különleges bánásmódot igénylő gyermekek fejlesztéséről vagy általában a neveléssel kapcsolatos módszerekről. A tényleges továbbképzések tartalma esetében aránytalanul hangsúlyosan jelenik meg az egészséges életmódra nevelés. Bár ezt követően a továbbképzések tartalma inkább a pedagógusok fejlesztési igényekhez látszik igazodni.

Érdekelt bennünket, hogy a pedagógusok mennyire elégedettek az iskolavezetés munkájával a tervezettség, a szervezettség, az ellenörzés-visszacsatolás és az új kezdeményezések felkarolása vonatkozásában. Mindezek a tulajdonságok a tudatos és felelős vezetői magatartás jellemzői (Kérjük, határozza meg, hogy Ön mennyire elégedett az iskolavezetés munkájával az alábbi területeken! „1 = egyáltalán nem vagyok elégedett”, „2 = inkább nem vagyok elégedett”, „3 = elégedett is vagyok, meg nem is”, „4 = inkább elégedett vagyok”, „5 = teljes mértékben elégedett vagyok" és Véleménye szerint az iskola mely területeken tartja a legfontosabbnak a pedagógusai szakmai fejlödését? Megadott kategóriákból három legfontosabb jelölése).

\begin{tabular}{|c|c|c|c|c|c|}
\hline \multirow[b]{2}{*}{ kategóriák } & \multicolumn{5}{|c|}{$\begin{array}{l}\text { A pedagógusok elégedettsége az iskolaveze- } \\
\text { tés munkájával (tervezettség, szervezettség, } \\
\text { ellenőrzés-visszacsatolás, új kezdeményezé- } \\
\text { sek felkarolása)/gyakoriságok (fô) } \mathrm{N}=113\end{array}$} \\
\hline & 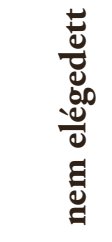 & 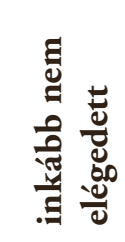 & 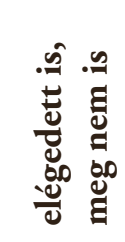 & 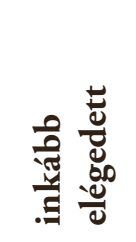 & 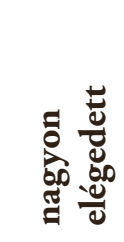 \\
\hline $\begin{array}{l}\text { pedagógusok diszciplináris tudásá- } \\
\text { nak fejlesztése }\end{array}$ & 0 & 0 & 4 & 5 & 4 \\
\hline $\begin{array}{l}\text { pedagógusok módszertani tudásá- } \\
\text { nak fejlesztése }\end{array}$ & 0 & 0 & 32 & 35 & 21 \\
\hline $\begin{array}{l}\text { pedagógusok szakmai előmenetelé- } \\
\text { nek segítése }\end{array}$ & 0 & 0 & 17 & 19 & 13 \\
\hline
\end{tabular}




\begin{tabular}{|c|c|c|c|c|c|}
\hline \multirow[b]{2}{*}{ kategóriák } & \multicolumn{5}{|c|}{$\begin{array}{l}\text { A pedagógusok elégedettsége az iskolaveze- } \\
\text { tés munkájával (tervezettség, szervezettség, } \\
\text { ellenőrzés-visszacsatolás, új kezdeményezé- } \\
\text { sek felkarolása)/gyakoriságok (fô) } \mathrm{N}=113\end{array}$} \\
\hline & 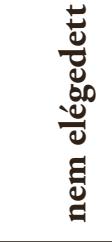 & 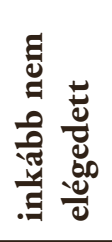 & 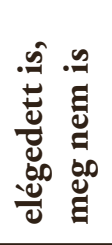 & 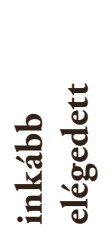 & 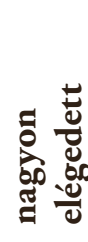 \\
\hline $\begin{array}{l}\text { pedagógusok felkészítése helyi kuta- } \\
\text { tásokban való közreműködésre }\end{array}$ & 0 & 0 & 2 & 3 & 5 \\
\hline $\begin{array}{l}\text { pedagógusok IKT-kompetenciáinak } \\
\text { fejlesztése }\end{array}$ & 0 & 0 & 21 & 24 & 13 \\
\hline
\end{tabular}

\section{3 táblázat: A pedagógusok elégedettsége a vezetés tudatos tevékenységével a szakmai fejlesztés vonatkozásában}

A fenti táblázat (3. táblázat) értelmezéséhez szükséges megjegyeznünk, hogy a pedagógusok elégedettsége az iskolavezetés munkájával kérdéskörnek több változója volt. A táblázat csak azokat az adatokat tartalmazza, amelyeknél a négy változóval leírt (tervezettség, szervezettség, ellenörzés-visszacsatolás, új kezdeményezések felkarolása) vezetői tudatosság a pedagógusok szerint együttesen érvényesül a felsorolt kategóriákban. Így a nem elégedettek itt most nem jelennek meg.

A pedagógusok elsősorban a saját módszertani tudásuk fejlesztése vonatkozásában érzik az iskolavezetés tudatosságát és felelős, átgondolt tevékenységét (56 megemlítés inkább és nagyon elégedett) (vö. 6. fejezet). Ezt követi a pedagógusok IKT-kompetenciáinak fejlesztése (37), majd a szakmai előmenetel támogatása (32). A másik oldalon viszont látható, hogy arányaiban viszonylag sokan gondolják, hogy a tudatosság nem mindig érvényesül ugyanezeken a területeken, erre utal az elégedett is, meg nem is válaszok viszonylag magas aránya. Kevesen jelölték be a diszciplináris tudás fejlesztését és a helyi kutatásokban való részvételre való felkészítést, bár ezeknél is az inkább elégedett és nagyon elégedett válaszokat jelölték meg. A válaszok viszonylag kisebb gyakorisága azzal magyarázható, hogy a pedagógusok nem tulajdonítanak akkora jelentőséget a két területnek.

A következő kérdéskör az volt, hogy mit tartanak maguk a pedagógusok a gyakorlóiskola legfontosabb feladatainak, és azon belül mennyire hangsúlyosan van jelen a szakmai fejlesztés (Ön milyen lehetöségekkel él a továbbképzéseken kivül szakmai fejlödése érdekében? Több választ is megjelölhet.). 
A 4. táblázat (lásd Melléklet) adatai szerint a pedagógusok a szakmai fejlesztést fontos, de nem meghatározó feladatnak tartják a gyakorlóiskola életében. A felsorolt 21 kategóriából, az első tíz kategóriába csak négy a szakmai fejlesztésre vonatkozó kategória került be: a más iskolák számára való példamutatás (átlag = 4,55), a folyamatos pedagógiai fejlesztés (átlag = 4,42), a szakmai karrier folyamatos támogatása (átlag = 4,22) és szaktudományos képzésük (átlag = 4,17). A tudásmegosztás (átlag $=4,15)$, valamint a kutatásokba való bekapcsolódás (átlag = 3,86), esetleg a hazai horizont kiszélesítése nemzetközivé (átlag = 3,72) kevésbé fontosnak tartott feladatok.

Itt érdemes összevetni, hogy milyen szakmai területeket neveztek meg a pedagógusok a vezetés prioritásaiban, és mit tartanak a pedagógusok a legfontosabbnak szakmai fejlődésük szempontjából (Véleménye szerint az iskola mely területeken tartja a legfontosabbnak a pedagógusai szakmai fejlödését? Megadott kategóriákból három legfontosabb jelölése és Jelenleg milyen területeken tartja a leginkább szükségesnek a saját szakmai fejlödését? Több választ is megjelölhet.).

A legnagyobb lefedettség (5. táblázat, lásd a Melléklet) a pedagógusok véleménye szerint az iskolavezetés és a pedagógusok prioritásai között a pedagógusok módszertani/ szakmódszertani tudásának fejlesztése területén valósul meg, azaz ezen a területen történő fejlesztés vonatkozásában gondolják úgy, hogy azonosulni tudnak a szakmai vezetés elképzeléseivel. A legkisebb a lefedettség a művészeti nevelés, a tanárjelöltek szakmai fejlődésének segítése, az idegen nyelvi képzés, a kutatásmódszertani képzés fontosságának megítélése, a különleges bánásmódot igénylő gyermekek fejlesztése, a környezeti nevelés és a pedagógusok diszciplináris tudásának fejlesztése vonatkozásában.

Ugyanehhez a kérdéskörhöz tartozik, hogy a pedagógusok szerint mikor válhat a gyakorlóiskola szakmai fejlesztő iskolává (Kérjük, fejezze be az alábbi mondatot azzal a gondolatával, amelyet a legtalálóbbnak tart! A jó gyakorlóiskola akkor válhat szakmai fejlesztö iskolává, ha...).

\begin{tabular}{|l|c|c|}
\hline $\begin{array}{l}\text { kategóriacsoportok } \\
\mathbf{N}=\mathbf{1 0 2}\end{array}$ & $\begin{array}{c}\text { gyakoriság } \\
\text { (fö) }\end{array}$ & $\begin{array}{c}\text { százalékos } \\
\text { gyakoriság (\%) }\end{array}$ \\
\hline magas szakmai tudás & 41 & 23 \\
\hline pedagógusok szakmai fejlődése, elkötelezettség & 31 & 16 \\
\hline tudásátadás, megosztás, egymással és más iskolákkal & 13 & 7 \\
\hline együttműködés az egyetemmel & 9 & 5 \\
\hline hallgatók támogatása & 8 & 4 \\
\hline szakmai autonómia & 1 & 0 \\
\hline
\end{tabular}

8.6. táblázat: A pedagógusok által fontosnak tartott tényezők a szakmai fejlesztő iskolává váláshoz 
Az összes válaszadó 181 választ adott a metaforakérdésre. A válaszokat 21 nagyobb kategóriába osztottuk, majd megvizsgáltuk az egyes kategóriákon belül a megemlítések számát. A fenti táblázatban (6. táblázat) csak a szakmai fejlesztés kategóriáit foglaltuk össze. A pedagógusok a magas szintű szakmai tudást az összes kategória közül is a legelső helyre sorolták (23\%). A szakmai fejlődés szempontjából ezen kívül a fejlődésre való igényt és elkötelezettséget és az egymás közötti és más iskolákkal, intézményekkel való tudásmegosztást tartják a szakmai fejlesztő iskola legfontosabb ismérveinek. Meglepő, hogy a válaszadók közül igen kevesen nevezték meg az egyetemmel való együttműködést és a hallgatók támogatását. Ezek az adatok számunkra azt a következtetést engedik meg, hogy a pedagógusok elsősorban saját magas szintű szakmaiságukat tartják a gyakorlóiskola legfontosabb ismérvének. Megkockáztatjuk azt a kijelentést, hogy ez a szakmaiság elsősorban az iskolában tanuló gyermekek igényeinek ismeretét és a gyerekek nevelésével kapcsolatos szakmai tudást jelenti. Az egyetemmel együtt történő tanárképzés, azaz a jövő pedagógusainak támogatása nem megahatározó szakmai cél számukra. Ez összecseng a 2. táblázat adatai alapján megfogalmazott következtetéseinkkel.

Az első hipotézisünket, amely szerint a pedagógusok nézetei szerint az iskolavezetés nagy hangsúlyt helyez a pedagógusok szakmai tudásának tervszerü és tudatos fejlesztésre, mindez saját nézeteikben úgy tükröződik, hogy ők maguk is a magas szintü szakmai tudást tartják az iskola fejlődése szempontjából a legfontosabbnak, alátámasztottuk.

Ugyanakkor meg kell jegyeznünk, hogy bizonyos jellemzők, amelyek a szakmai fejlesztő iskola fontos ismérvei, nem jelennek meg sem az iskolavezetés, sem pedig a pedagógusok nézeteiben kiemelt helyen. Ilyenek például az iskolavezetőknél a tanárjelöltek szakmai fejlődésének támogatása (7. hely), a pedagógusok reflektív tanításának a fejlesztése (13. hely), a pedagógusok felkészítése helyi kutatásokra (13. hely), a pedagógusoknál pedig a mentorálás (6. hely) vagy a kutatásmódszertani tudás (7. hely).

\subsection{A szakmai fejlődés és a pedagógus}

Kutatásunk e pontján fontosnak tartottuk, hogy a pedagógusok önmagukra vonatkozó nézeteit is megvizsgáljuk. Az első kérdés az volt, hogy hogyan értékelik a pedagógusok saját magukat a szakmai tudás és önfejlesztés vonatkozásában (Kérjük, értékelje az alábbi állításokat aszerint, hogy azok mennyire jellemzöek Önre szakmai tevékenysége során! „1 = egyáltalán nem jellemzö rám”, „2 = inkább nem jellemzö rám”, „3 = jellemzö is rám, meg nem is”, „4 = inkább jellemzö rám”, „5 = teljes mértékben jellemzö rám”, 8.7.táblázat, lásd Melléklet). A gyakorlós pedagógusok jelentős többsége kiválónak ítéli meg szakmai tudását (92,21\%), és folyamatosan keresi a megújulás lehetőségeit (85,8\%), elkötelezett a szakmai fejlődés irányában. Több mint fele $(63,7 \%)$ naprakész az új ismeretek követésében, ugyanakkor a fele osztaná meg tudását (50,4\%), és kevesebb mint fele tartana bemutatóórákat (46,9\%). 
Tovább haladva ezen a logikai szálon, annak kiderítésére, hogy a fentiekben kijelölt területek esetében van-e a pedagógusok között valamilyen különbség a pályán eltöltött évek, az iskolában való beosztás és a pedagógusfokozat vonatkozásában, varianciaanalízist végeztünk. Ennek alapján megállapítható, hogy a pedagógusok közül az általános iskolai tanítók gondolják a leginkább úgy, hogy kiváló szaktudással rendelkeznek $(r=0,005 ; \mathrm{p}$ $<0,05)$. A szakirodalom követése estében minél hosszabb ideje dolgoznak a gyakorlóban a pedagógusok, annál inkább nyomon követik azt $(\mathrm{r}=0,008 ; \mathrm{p}<0,05)$. Közülük is elsősorban az általános iskola felső tagozatában tanító pedagógusokra $(\mathrm{r}=0,007 ; \mathrm{p}<$ $0,05)$ és a mesterpedagógusokra jellemző a szakirodalmi tájékozottság. A bemutatóórák megtartását a legszívesebben a mesterpedagógusok $(\mathrm{r}=0,00 ; \mathrm{p}<0,05)$ vállalják. Az általános iskolai tanítók $(\mathrm{r}=0,014 ; \mathrm{p}<0,05)$, a középiskolai vezetőtanárok $(\mathrm{r}=0,051 ; \mathrm{p}>$ $0,05)$, a szakértő vagy szaktanácsadó tanárok, beosztás szerint pedig a mesterpedagógus fokozatba tartozók $(\mathrm{r}=0,015 ; \mathrm{p}<0,05)$ azok, akik a leginkább tartanának mủhelyfoglalkozásokat $(\mathrm{r}=0,01 ; \mathrm{p}<0,05)$.

Az előzőekben is láthattuk, hogy a szakmai tudás és a szakmai fejlődésért való elkötelezettség a gyakorlóiskola pedagógusai számára prioritást élvez. Adódott tehát a kérdés, hogy a szakmai tudás milyen részterületeit tartják a legfontosabb fejlesztendő területeknek (Jelenleg mely területeken tartja a leginkább szükségesnek a saját szakmai fejlödését? Több választ is megjelölhet.).

Számunkra nem meglepő (8 táblázat, lásd Melléklet), hogy a legmagasabb átlag az IKT-kompetenciák területén (átlag = 0,44) született. Ezt követi a különleges bánásmódot igénylő tanulók fejlesztésének (átlag = 0,41), a szakmódszertani tudás fejlesztésének (átlag = 0,33 ), majd a nevelést segítő módszertani tudás fejlesztésének igénye (átlag=0,33). A korábban megfogalmazott következtetésünket támasztja alá az a tény, hogy a kutatásmódszertani tudást a válaszadók 11,8\%-a nevezte csak meg (vö. Zagyváné, 2016).

Kézenfekvő volt a kérdés, hogy a pedagógusok a fejlesztés, önfejlesztés mely eszközeivel, módszereivel élnek a leginkább, és azokon belül is milyen hagyományos és az új típusú eszközök és módszerek jelennek meg (Ön milyen lehetöségekkel él a továbbképzéseken kivül szakmai fejlödése érdekében? Több választ is megjelölhet.). Már a pedagógusok önértékelésénél (7. táblázat) is hangsúlyos szerepet kapott a szakirodalom terén való tájékozottság. A 9. táblázat (lásd Melléklet) átlagai még inkább megerősítik ezt, vagyis a szakirodalom olvasása kimagaslóan a legfontosabb önfejlesztési eszköz (átlag = 0,86). A válaszadók előszeretettel használják más közösségek adatbázisát (átlag = 0,37), járnak egymás óráit látogatni (átlag $=0,31$ ), élnek az egyetem által szervezett (átlag $=0,28$ ) és más hazai konferenciákon való előadással (átlag = 0,27 ) mint a tudásmegosztás hagyományos lehetőségével. A kutatás útján szerzett tudás publikálása (átlag $=0,07$ ) és az IKT-eszközök felhasználása a tudásmegosztásra (átlag $=0,05)$ csak kevés pedagógusra jellemző. 
Színesíti a képet, ha közelebbről megvizsgáljuk, hogy a pedagógusok milyen szakmai területek fejlesztésére alkalmazzák az önfejlesztés legelterjedtebb módjait (10. táblázat, lásd Melléklet). A legnépszerűbb területek a pedagógusok módszertani fejlesztése és a tanulók kompetenciafejlesztése (megjelölés $=140-140)$, ezt követi a tehetséggondozás (megjelölés = 121), majd a pedagógusok IKT-kompetenciáinak fejlesztése. A szakmai folyóiratok, szakkönyvek tanulmányozását a módszertani fejlesztés, a tanulók kompetenciafejlesztése és a tanulmányi teljesítmény javítása érdekében használják elsősorban. Más tantestületek, szakmai közösségek adatbázisait elsősorban a tanulók kompetenciafejlesztésére, a tehetséggondozás és a módszertani kultúra gazdagítására használják. Az egyetem által szervezett konferenciák adta lehetőségekkel elsősorban a módszertani fejlesztés, a tanulók kompetenciáinak a fejlesztése és a tehetséggondozás területén élnek. Az óralátogatások tapasztalatait elsősorban a tanulók kompetenciáinak fejlesztése, a tehetséggondozás és a módszertani fejlődés érdekében kívánják kamatoztatni.

Arra vonatkozóan, hogy van-e valamilyen összefüggés a pedagógusok szakmai önértékelése és az önfejlesztés érdekében alkalmazott módszerek mennyisége között (Kérjük, értékelje az alábbi állitásokat aszerint, hogy azok mennyire jellemzöek Önre szakmai tevékenysége során? „1 = egyáltalán nem jellemzö rám”, „2 = inkább nem jellemzö rám”, „3 = jellemzö is rám, meg nem is”, "4 = inkább jellemzö rám”, "5 = teljes mértékben jellemzö rám” és Ön milyen lehetöségekkel és a továbbképzéseken kivül szakmai fejlödése érdekében? Több választ is megjelölhet.), a 8.11-es táblázat (lásd Melléklet) segítségével kapjuk meg a választ. A táblázat adatai egy ötfokozatú Likert-skálán mért értékekre vonatkoznak, ahol az 5 a teljes mértékben jellemző, vagyis minél magasabb az érték, annál szorosabb az összefüggés a pedagógus önértékelésével az adott szakmai terület és az alkalmazott önfejlesztési módszer között. Nem meglepő, hogy azok, akik valamilyen szakmai témát kutatnak, és arról publikálnak, vagy rendszeresen járnak konferenciákra, náluk a legmagasabb a szakmai önértékelés átlaga (8 szakmai területen maximálisra értékelték önmagukat). Az viszont már izgalmas összefüggés, hogy azok, akik szakmai szempontból a legsokoldalúbban képzik önmagukat (11-féleképpen), ők érzik úgy a leginkább, hogy képesek korrigálni saját pedagógiai tevékenységüket, fontosak számukra a gyerekek visszajelzései, továbbá a szülők, kollégáik és vezetőik visszajelzései is. Vagyis levonhatjuk azt a következtetést, hogy az adaptivitás képessége sok pedagógus esetében nemcsak a tanítás-nevelés viszonylatában nyilvánul meg, hanem az önfejlesztés vonatkozásában is.

Még részletesebben vizsgáltuk meg a szakmai önértékelésen belül a kifejezetten a szakmai fejlődésre vonatkozó területek és az önfejlesztés módjai közötti összefüggéseket (Kérjük, értékelje az alábbi állitásokat aszerint, hogy azok mennyire jellemzöek Önre szakmai tevékenysége során? „1 = egyáltalán nem jellemzö rám”, „2 = inkább nem jellemzö rám”, „3 = jellemzo" is rám, meg nem is”, „4 = inkább jellemzö rám”, "5 = teljes mértékben jellemzö rám” és Ön 
milyen lehetöségekkel él a továbbképzéseken kivül szakmai fejlödése érdekében? Több választ is megjelölhet.). Az önértékelés kiemelt területei rangsorolva: kiváló szakmai tudással rendelkezem (1.), nyomon követem a pedagógiai, pszichológiai, módszertani szakirodalmat (2.), szivesen tartanék bemutatóórát kollégáknak (12.), szivesen tartanék mühelyfoglalkozásokat kollégáknak (13.), keresem a folyamatos megújulás lehetöségeit (16.). Itt is megerősítést nyert (8.12 táblázat, lásd Melléklet), hogy a kiemelt területeken a kutatással, publikálással foglalkozó kollégák szakmai önértékelése a legmagasabb (három területen maximális az átlag (az összes átlag = 4,6). Továbbá a válaszadók a folyamatos megújulásra való törekvést (összes átlag = 4,27) és a kiváló szaktudásukat (összes átlag $=4,18$ ) értékelik a legjellemzőbb tulajdonságuknak. Azok a pedagógusok, akik a szakmai fejlődéshez az óralátogatásokat (átlag = 5) és hazai konferenciákat preferálják, a szakmai tudásukat értékelik a legmagasabbra (átlag = 5), a korszerü IKT-eszközöket alkalmazó pedagógusok a folyamatos megújulásra való törekvésben érzik magukat a legkiemelkedőbbnek (átlag = 5).

Külön figyelmet igényelnek a pedagógusok által látogatott továbbképzések. Az erre vonatkozó adatokat az iskolavezetés bocsátotta rendelkezésünkre. A szakirodalom is alátámasztja, hogy a továbbképzések jelentik manapság a pedagógusok körében az egyik legelterjedtebb önfejlesztési módszert a szakirodalom nyomon követése után. Nincs ez másként a gyakorlóiskolában sem.

\begin{tabular}{|c|c|c|c|}
\hline $\begin{array}{c}\text { továbbképzések } \\
\text { száma }\end{array}$ & összes résztvevő & témák száma & $\begin{array}{c}\text { pályázatok } \\
\text { keretén belüli } \\
\text { továbblépzések }\end{array}$ \\
\hline 28 & 388 & 15 & 8 \\
\hline
\end{tabular}

8.13. táblázat: Továbbképzések, amelyeken a pedagógusok részt vettek

Kiemelkedően magas nemcsak a továbbképzések, hanem az azokon résztvevők száma is (13. táblázat). Az egy fơre jutó továbbképzések száma a tantestületben (388/132 fö) 2,56 db. A továbbképzések közel egy negyede pályázatok keretén belül valósult meg. 


\begin{tabular}{|l|c|c|}
\hline továbbképzések témái & darab & résztvevók \\
\hline egészséges életmódra nevelés & 6 & 97 \\
\hline neveléssel kapcsolatos módszertani & 4 & 59 \\
\hline szaktárgyi & 3 & 40 \\
\hline IKT-kompetenciák fejlesztése & 2 & 31 \\
\hline tehetségfejlesztés & 3 & 30 \\
\hline társas kapcsolatok fejlesztése & 1 & 18 \\
\hline családpedagógia & 1 & 18 \\
\hline olvasáspedagógia & 1 & 15 \\
\hline népismeret & 1 & 13 \\
\hline honismeret & 1 & 12 \\
\hline környezettudatos magatartás kialakítása & 1 & 12 \\
\hline elsősegélynyújtás & 1 & 12 \\
\hline vezetőképzés & 1 & 11 \\
\hline könyvtár-pedagógia & 1 & 10 \\
\hline esélyegyenlöség & 1 & 10 \\
\hline összes & 28 & 388 \\
\hline
\end{tabular}

\subsection{4. táblázat: A továbbképzések témái és az azokon részt vett pedagógusok száma}

A továbbképzések témái is igen nagy változatosságot mutatnak (14. táblázat). Kiemelkedő az egészséges életmódra neveléssel kapcsolatos továbbképzések aránya és a képzéseken részt vevők száma. Olyan különleges területek is megjelennek, mint a családpedagógia, olvasás- és könyvtár-pedagógia. A pedagógusok által megjelölt fontosabb fejlesztésre váró területekkel összevetve (8. táblázat) jól látható, hogy míg ott az IKT-kompetenciák, a különleges bánásmódot igénylő gyerekek fejlesztését segítő módszertani és a szakmódszertani ismeretek az elsősorban fejlesztésre váró területek, addig a továbbképzéseknél a neveléssel kapcsolatos módszertani, a szaktárgyi és az IKT-kompetenciák a sorrend. A továbbképzések témái tehát nagyrészt lefedik a fejlesztésre váró területeket, bár a továbbképzéseknél vezető egészséges életmódra nevelés a fejlesztési igényeknél nem jelenik meg kiemelt formában.

A továbbiakban azt vizsgáltuk meg, hogy a vizsgált időszakot megelőző öt évben a pályázatok mennyiben segítették a pedagógusok szakmai fejlődését (Véleménye szerint milyen hatást gyakorol a pályázatok megvalósitása a tantestület életére? 1= Egyáltalán nem 
jellemzö, 2 = Inkább nem jellemzö, 3 = Jellemzö is, meg nem is, $4=$ Inkább jellemzö, $5=$ Teljes mértékben jellemzô). A pedagógusok jelentős többsége számára (8.15 táblázat, lásd Melléklet) a pályázatok leginkább szakmai kihívást jelentettek (megjelölte $=80 \%)$. Több mint fele a válaszadóknak fontosnak tartotta a motivációt az iskolai munkában és a szakmai előmenetelben nyújtott támogatást. A képet árnyalja, hogy $62,8 \%$ úgy ítélte meg, hogy a pályázatok folyamatos túlterhelést jelentettek a tantestület számára, amelyet ellensúlyozott a szakmai előmenetel támogatása és az anyagi elismertség (megjelölte $=72,8 \%$ ).

Érdemes megnézni, hogy kik azok, akik számára elsősorban szakmai kihívást jelentettek a pályázatok.

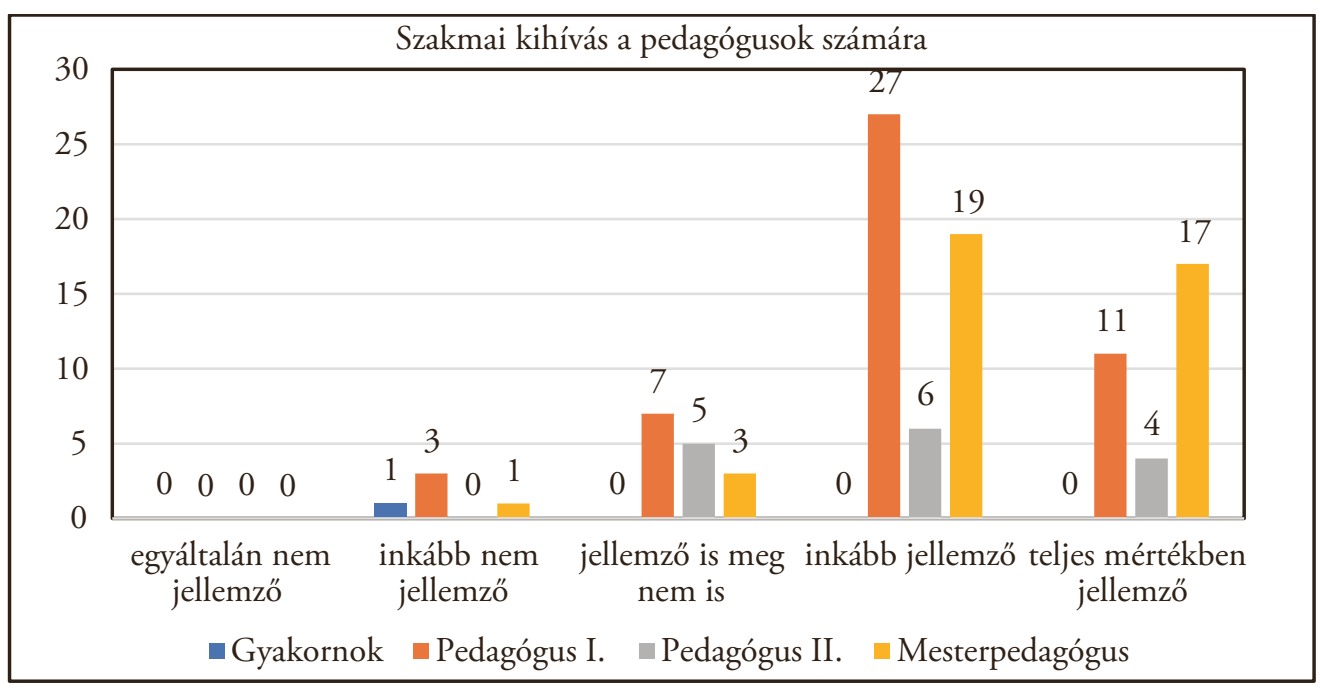

\section{1. ábra: Szakmai kihívás a pedagógusok számára}

Az ábrából látható (1.ábra), hogy a legtöbben a pedagógus I. (megjelölte = 79\%) és a mesterpedagógus (megjelölte $=90 \%$ ) kategóriába tartozók élték meg a pályázatokat mint szakmai kihívást. A pedagógus II. kategóriába tartozók esetében egyenletes a megoszlás azok között, akik számára a legnagyobb, nagy és kisebb mértékủ kihívást jelentették a pályázatok. 


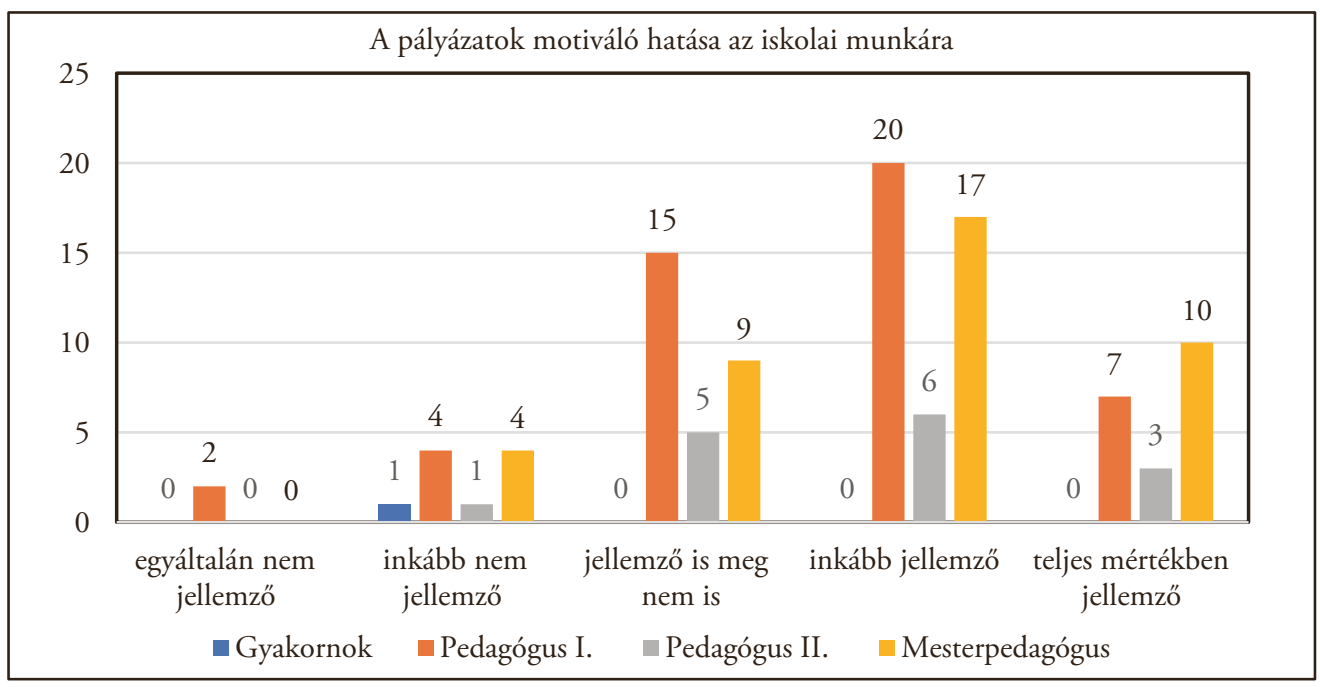

\section{2. ábra: A pályázatok motiváló hatása az iskolai munkára}

A szakmai kihívással összecseng, hogy a pályázatok iskolai munkában való motiváló erejének a megítélése vonatkozásában is a pedagógus I. (megjelölte $=56 \%$ ) és a mesterpedagógus kategóriába tartozók (megjelölte = 67,5\%) voltak azok, akik számára leginkább húzóerőt jelentettek, ugyanakkor a pedagógus I. kategóriába tartozóknál érdekes, hogy a válaszadók 31\%-a (15 fó) számára azért nem volt egyértelmü ez a motiváció (2. ábra).

A szakmai előmenetel támogatása vonatkozásában is érdemes kicsit közelebbről megvizsgálni e kérdést.

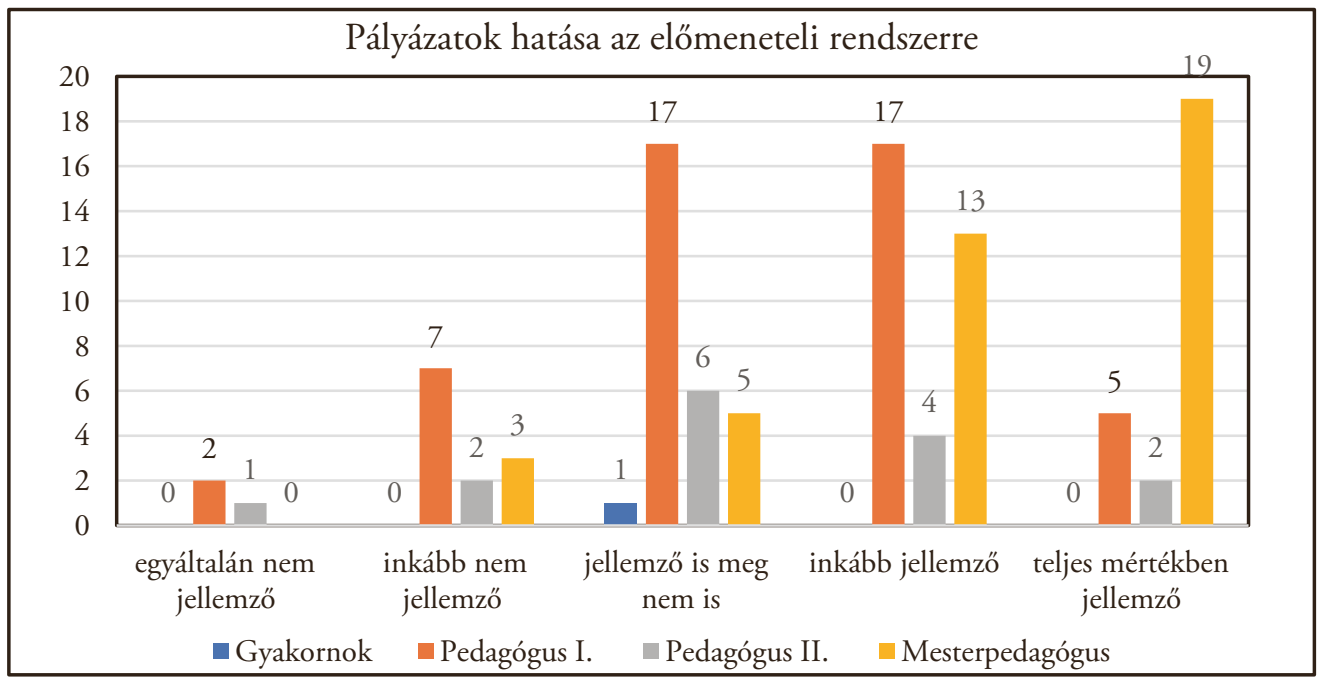

8.3. ábra: Pályázatok hatása az előmeneteli rendszerre 
Egyértelműen a mesterpedagógusok azok, akik leginkább úgy vélik, hogy a pályázatok támogatták őket a pedagógus-előmeneteli rendszerben, 40 föből 19 fö (megjelölte = 47,5\%) teljes mértékben jellemzőnek tartja ezt (3. ábra). A pedagógus I., pedagógus II. és a gyakornoki fokozatba tartozók több mint fele úgy ítélte meg, hogy jellemző is meg nem is, inkább nem jellemző vagy egyáltalán nem jellemző ez a támogatás.

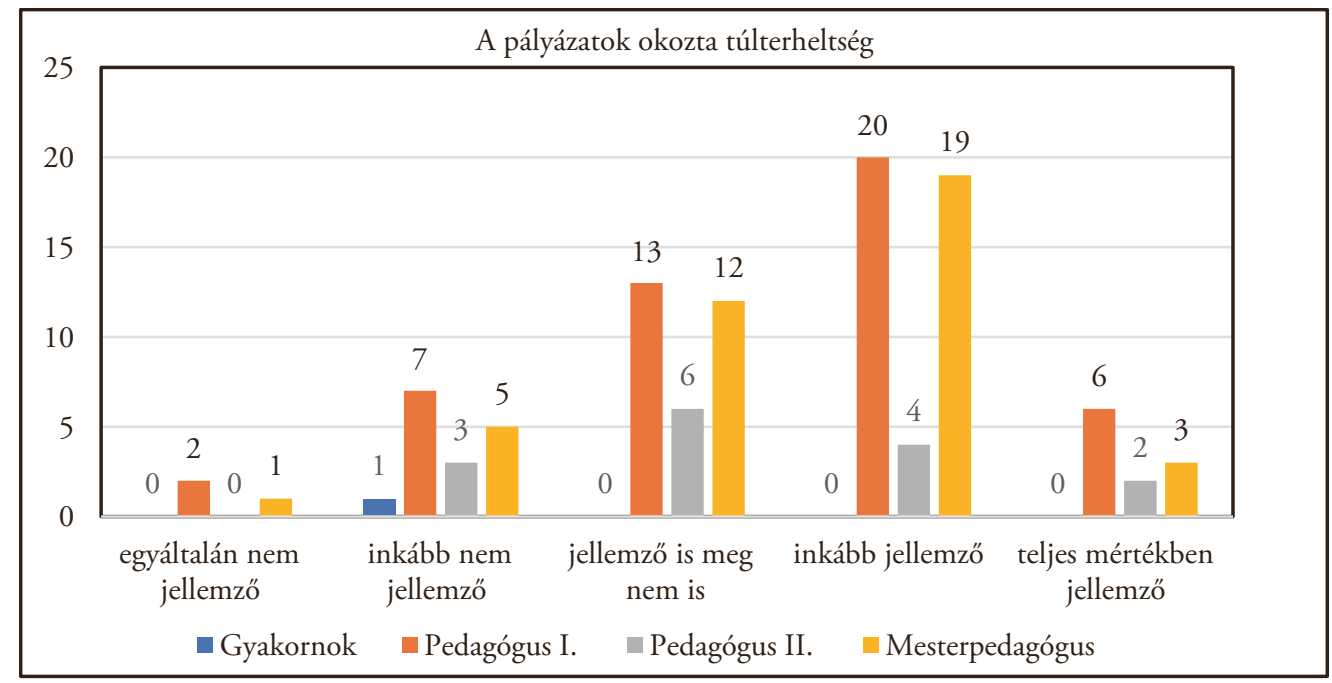

\section{4. ábra: A pályázatok okozta túlterheltség}

Tovább vizsgálva a pályázatok hatását a pedagógusfokozatok vonatkozásában, a pedagógus I. és a mesterpedagógus kategóriába tartozókat figyelemmel követve látható, hogy a mesterpedagógusok 55\%-a (22 fó a 40-ből) inkább jellemezőnek vagy teljes mértékben jellemzőnek tartotta a túlterheltséget (4. ábra). A pedagógus I. kategóriába tartozóknál ez az arány 54\% (26 fö a 48-ból) volt. 


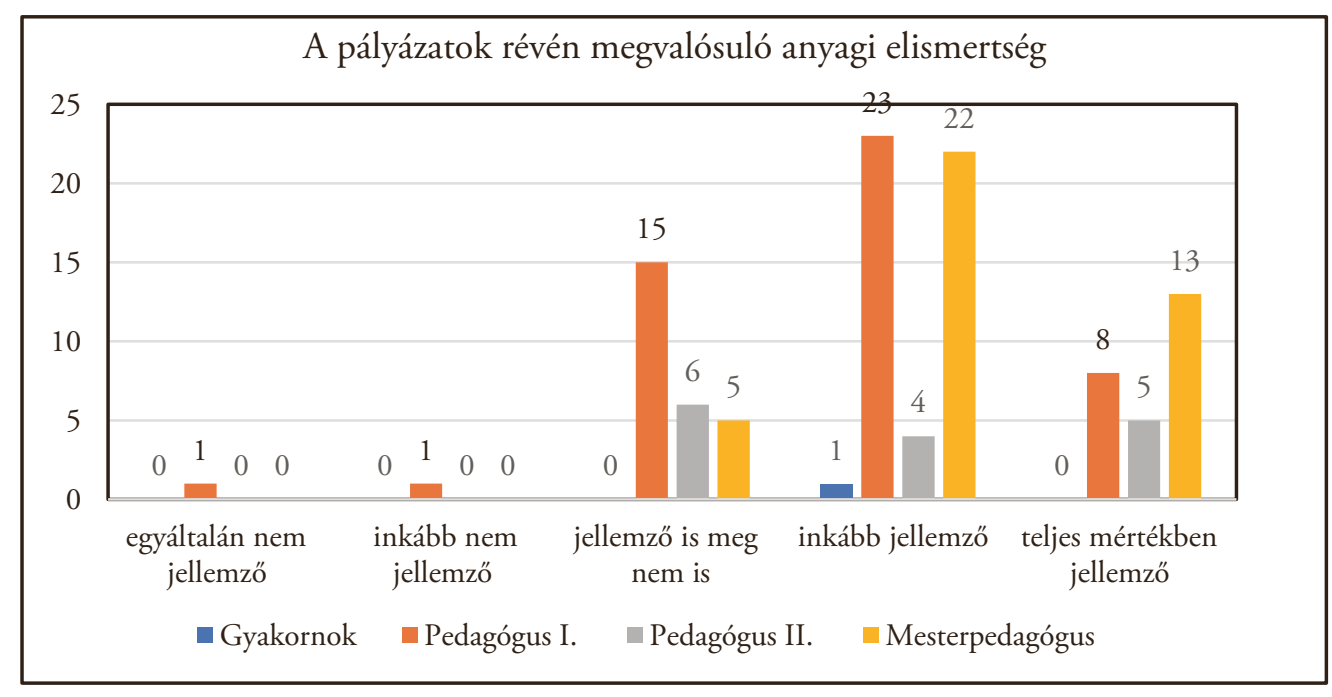

\section{5. ábra: A pályázatok révén megvalósuló anyagi elismertség}

$\mathrm{Az}$ anyagi elismertség tekintetében (5. ábra) egyértelmüen a mesterpedagógusok (megjelölte $=87,5 \%$ ) érezték úgy, hogy inkább vagy teljes mértékben támogatták őket a pályázatok (35 fö a 40-ből). A pedagógus I. kategóriába tartozók esetében ez az arány 64,5\% (31 fó a 48-ból). Még a pedagógus II. kategóriába tartozók is elismerték a pályázatok pozitív hatását az anyagi előrejutás területén, bár arányaikban ők inkább az ingadozók közé tartoznak.

A fenti adatokat elemezve tehát látható, hogy az összes válaszoló pedagógus közül elsősorban a mesterpedagógusok és a pedagógus I. kategóriába tartozók azok, akik a pályázatok kínálta lehetőségekkel a leginkább éltek és azokból a legtöbbet profitáltak.

\subsection{A tudásmegosztás mint a pedagógusok számára megfogalmazott szakmai elvárás}

A pedagóguséletpálya-modell és a szakmai fejlesztő iskolák koncepciója is egyik nagyon fontos szakmai elvárásként fogalmazza meg a tudásmegosztást tantestületen belül, a tantestület és más iskolák vonatkozásában, de nem tekinthetünk el a gyakorlóiskola és az egyetem együttműködésén alapuló tudásmegosztástól sem. Érdemes tehát ennek a kérdésnek egy kicsit több figyelmet szentelnünk.

Először azt néztük meg, hogy a gyakorlóiskola legfontosabb feladatai között mennyire tartják fontosnak a példamutatást és a pedagógiai fejlesztések, innovációk szakmai disszeminálását (megosztását) más iskolák számára az egész tantestület vonatkozásában, majd leszűkítettük a kört azokra a pedagógusokra, akik a vizsgálat előtti 5 évben tartottak valamilyen továbbképzést. 
A gyakorlóiskola feladatai közül a példamutatás más iskolák számára 4,55 átlaggal a negyedik, a tudásmegosztás, disszeminálás 4,15 átlaggal a tizenegyedik a rangsorban 21 feladat közül (8.4. táblázat), azaz az utóbbi nem tartozik a kiemelten fontos feladatok közé.

A pedagógusok jelentős része mégis meg kíván felelni a tudásmegosztás szakmai elvárásának. Főleg a továbbképzések megtartása területén vették ki részüket (Ön tartott valamilyen szakmai továbbképzést az elmúlt öt évben? Igen, Nem).

\begin{tabular}{|c|c|c|}
\hline kategóriák $\mathbf{N}=\mathbf{1 0 2}$ & gyakoriság (fö) & százalékos gyakoriság (\%) \\
\hline igen & 66 & 64,7 \\
\hline nem & 36 & 35,3 \\
\hline
\end{tabular}

\subsection{6. táblázat: Az elmúlt öt évben tartott továbbképzések aránya}

A válaszadók több mint fele tartott valamilyen továbbképzést a vizsgálat előtti öt évben (16. táblázat). Ez az adat igen nagy aktivitást mutat, bár a szakmai fejlesztő iskola elvárásaihoz képest még nem tekinthető elegendőnek.

Megnéztük, hogy a továbbképzéseket tartott kollégáknak milyen az eloszlása a pedagógusfokozatok és az iskolában eltöltött évek viszonyában.

\begin{tabular}{|c|c|c|}
\hline kategóriák $\mathbf{N}=\mathbf{1 0 2}$ & gyakoriság (fö) & százalékos gyakoriság (\%) \\
\hline Gyakornok & 0 & 0 \\
\hline Pedagógus I. & 33 & 32,35 \\
\hline Pedagógus II. & 6 & 5,8 \\
\hline Mesterpedagógus & 9 & 8,8 \\
\hline Kutatótanár & 0 & 0 \\
\hline Nem válaszolt & 54 & 52,9 \\
\hline Összes & 102 & 100 \\
\hline
\end{tabular}

\subsection{7. táblázat: Továbbképzések eloszlása a pedagógusfokozat vonatkozásában}

A táblázat alapján elmondható, hogy a megkérdezettek közül 54 fö nem jelölte meg, hogy milyen pedagóguskategóriába tartozik (17. táblázat). Ez nagymértékben nehezíti bizonyos tendenciák megállapítását. A válaszadók közül a pedagógus I. kategóriába tartozók vettek részt a legnagyobb számban továbbképzések megtartásában.

Sajnos az iskolában eltöltött évek vonatkozásában nem tudunk következtetéseket megfogalmazni (18. táblázat, lásd Melléklet), mivel a beazonosíthatóság miatti félelmükből 
kifolyólag sokan nem jelölték be (59 fö), hogy mióta dolgoznak a gyakorlóiskolában. A kapott adatok alapján nem vonhatók le a tendenciákra vonatkozó következtetések.

A továbbképzéseket tartott pedagógusok megoszlása az iskola két telephelye vonatkozásában nem tekinthető meghatározó tényezőnek ebben a kérdésben (19 táblázat, lásd Melléklet).

További kérdésként merült fel, hogy akik a vizsgált időszak előtti öt évben továbblképzéseket tartottak, mennyire tartják fontosnak a tudásmegosztást és a példamutatást más iskoláknak (Véleménye szerint mik a gyakorlóiskola legfontosabb feladatai? Több választ is megjelölhet., 20. és 21. válaszok és Ön tartott szakmai továbbképzést az elmúlt öt évben? Igen, Nem).

\begin{tabular}{|c|c|c|c|c|}
\hline \multirow[b]{3}{*}{ kategóriák } & \multicolumn{4}{|c|}{$\begin{array}{l}\text { Az elmúlt öt évben továbbképzéseket tartott pedagógusok } \\
\text { szerint } N=66\end{array}$} \\
\hline & \multicolumn{2}{|c|}{$\begin{array}{l}\text { a pedagógiai fejlesztések, } \\
\text { innovációk szakmai disszemi- } \\
\text { nálásának feladata más iskolák } \\
\text { számára/ gyakoriság (fő) }\end{array}$} & \multicolumn{2}{|c|}{$\begin{array}{l}\text { példamutatás más iskolák } \\
\text { számára feladata/gyakoriság } \\
\text { (fó) }\end{array}$} \\
\hline & választotta & $\begin{array}{l}\text { nem } \\
\text { választotta }\end{array}$ & választotta & $\begin{array}{l}\text { nem } \\
\text { választotta }\end{array}$ \\
\hline nem fontos & 0 & 0 & 0 & 0 \\
\hline $\begin{array}{l}\text { inkább nem } \\
\text { fontos }\end{array}$ & 0 & 2 & 0 & 0 \\
\hline $\begin{array}{l}\text { fontos is meg } \\
\text { nem is }\end{array}$ & 2 & 12 & 0 & 7 \\
\hline inkább fontos & 13 & 29 & 10 & 15 \\
\hline nagyon fontos & 18 & 18 & 18 & 18 \\
\hline
\end{tabular}

8.20. táblázat: A tudásmegosztás és a más iskoláknak való példamutatás fontosságának megítélése a továbbképzéseket tartott pedagógusok szerint

Az adatokat elemezve láthatjuk, hogy többségben vannak azok, akik ezt a két kategóriát nem is jelölték meg (20. táblázat). Azok, akik azonban kiválasztották, meggyőződésesen hiszik, hogy a gyakorlóiskola fontos feladata az elért fejlesztések, innovációk megosztása más iskolák pedagógusaival és a példamutatás számukra.

A pedagógusok által tartott továbbképzéseket iskolai dokumentumok elemzése alapján vizsgáltuk, amelyeket az iskola vezetése tett számunkra elérhetővé. A továbbképzéseket 
lebontottuk témákra, továbbképzési alkalmak számára és a továbbképzések óraszámára. A legtöbb továbbképzést (21. táblázat, lásd Melléklet) az IKT-kompetenciák (11 alkalom és 449 darab óra), a módszertan (8 alkalom és 2079 darab óra), valamint a szakmai megújulás és előmenetel segitése (3 alkalom és 105 darab óra) terén tartották a pedagógusok. A legmagasabb óraszámot egyértelműen a módszertani továbbképzésék jelentették. Ez számunkra összecseng azzal, hogy a pedagógusok nagy hangsúlyt helyeznek a szakmai tudás magas színvonalára. Ebben érzik magukat erősnek, és ezt osztják meg saját tantestületen belül és más iskolák pedagógusaival.

A célcsoportokat tekintve (22. táblázat, lásd Melléklet) a legtöbb továbbképzés (megjelölte = $19 \mathrm{db}$ ) bármilyen pedagógus számára szólt, vagyis az általános jellegű, minden pedagógus számára kamatoztatható szakmai tudás átadása volt a legjellemzőbb, őket követték a középiskolai tanárok (megjelölte $=4 \mathrm{db}$ ), a szakvezetők (megjelölte $=4 \mathrm{db}$ ), a szaktanárok (megjelölte $=3 \mathrm{db}$ ), majd az általános iskolai tanárok (megjelölte $=2 \mathrm{db}$ ).

Elmondható tehát, hogy a továbbképzések széles vertikumában vettek részt a gyakorlóiskola pedagógusai mint képzők. Főleg a módszertani képzés az, amit a zászlójukra tűztek, de nem maradtak ki olyan célcsoportok sem, mint az intézményvezetők, óvodapedagógusok vagy éppen a külföldi tanárok.

Az előzőkből tehát jól látható, hogy a pedagógusok magasra értékelik szakmai tudásukat. Nagyon sokféleképpen fejlesztik magukat. Kiemelkedő azoknak a továbbképzéseknek a száma, amelyeken részt vettek. Bár a gyakorlóiskola tudásmegosztó szerepének nem tulajdonítanak akkora szerepet, mint a más iskolák számára nyújtott példamutatásnak, mégis kiemelkedő a tudásmegosztásban részt vevő pedagógusok száma. Mindez alátámasztja második hipotézisünket, amely szerint a gyakorlóiskolai pedagógusok saját szakmai tudásszintjének megítélése jelentős összefüggésben van a pedagógusok tudásmegosztásban való részvételének az arányával.

\subsection{Az egyetem és a gyakorlóiskola a szakmai fejlesztés vonatkozásában}

\subsubsection{A kutató pedagógus}

Korábban már szóltunk arról, hogy a szakmai fejlődés egyik módja valamilyen téma alaposabb feltárása, kutatása és az így megszülető tudás megosztása. Az előzőekben már hivatkoztunk a pedagóguséletpálya-modellre és a szakmai fejlesztő iskolák elvárásaira. Egy újabb elvárás tehát a kutatás és az általa történő szakmai fejlődés a pedagógus számára, de nem tekinthetünk el a hallgatók fejlesztésétől, az iskola szakmai megújulásától, nem beszélve az egyetemi oktatók szakmai megújulásáról. Ezért került vizsgálódásunk fókuszába, hogy az iskola eredményessége szempontjából a pedagógusok mennyire tartják fontosnak az egyetemmel való együttmüködést, a pedagógusok részvételét tudományterületi kutatásokban, 
a pedagógusok részvételét pedagógiai, pszichológiai kutatásokban, a pedagógusok folyamatos szakmai fejlesztését és a pedagógusok szaktudományos képzését (Véleménye szerint az alábbi tényezök közül melyek segitik elö a leginkább az iskola eredményességének növelését? Több választ is megjelölhet. és Véleménye szerint mik a gyakorloiskola legfontosabb feladatai? Több választ is megjelölhet.).

\begin{tabular}{|c|c|c|}
\hline $\begin{array}{c}\text { a pedagógusok által } \\
\text { fontosnak tartott } \\
\text { gyakorlóiskolai feladatok } \\
\text { kategóriák }\end{array}$ & a kategóriák átlaga & $\begin{array}{c}\text { az iskola } \\
\text { eredményességének } \\
\text { növelése az egyetem } \\
\text { és a gyakorló szoros } \\
\text { szakmai együttmúködése } \\
\text { által/átlag }\end{array}$ \\
\hline $\begin{array}{c}\text { egyetemmel való kutatási } \\
\text { együttmüködés }\end{array}$ & 3,86 & 4,03 \\
\hline $\begin{array}{c}\text { a pedagógusok részvétele } \\
\text { tudományterületi } \\
\text { kutatásokban }\end{array}$ & 3,45 & 3,53 \\
\hline $\begin{array}{c}\text { a pedagógusok részvétele } \\
\text { pedagógiai, pszichológiai } \\
\text { kutatásokban }\end{array}$ & 3,72 & 3,69 \\
\hline $\begin{array}{c}\text { a pedagógusok folyamatos } \\
\text { pedagógiai fejlesztése }\end{array}$ & 4,42 & 4,38 \\
\hline $\begin{array}{c}\text { a pedagógusok } \\
\text { szaktudományos képzése }\end{array}$ & 4,17 & 3,84 \\
\hline
\end{tabular}

8.23. táblázat: A gyakorlóiskolai feladatok és az iskolai eredményesség növelésének megítélése az egyetemmel való együttmúködés, a pedagógusok pedagógiai fejlesztése és szaktudományos képzése vonatkozásában

A gyakorlóiskola 21 feladatából a táblázatban megjelenő területek közül a pedagógusok folyamatos pedagógiai fejlesztése a 7. helyen, a pedagógusok szaktudományos képzése a 10. helyen, az egyetemmel való együttműködés a 14. helyen van. Az is látható, hogy a válaszadók szerint az egyetem és a gyakorlóiskola szoros szakmai együttműködése elsősorban a pedagógusok folyamatos pedagógiai fejlesztése (átlag $=4,38)$ területén biztosíthatja az iskola eredményességét. Jelentős még az egyetemmel való kutatási együttműködés (átlag $=4,03$ ), a pedagógusok szaktudományos képzése (átlag = 3,84) és a pedagógusok részvétele pedagógiai és pszichológiai kutatásokban (átlag = 3,69) (23.táblázat). 
Részletesebben is megvizsgáltuk, hogy a gyakorlóiskolai feladatok közül a kutatásra vonatkozókat mennyire tartják fontosnak az egész tantestületen belül (Véleménye szerint mik a gyakorlóiskola legfontosabb feladatai? Több választ is megjelölhet.).

\begin{tabular}{|c|c|c|c|c|}
\hline $\begin{array}{l}\text { kategória } \\
N=102\end{array}$ & 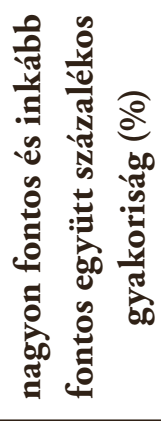 & 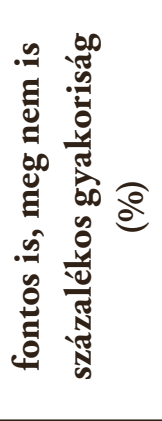 & 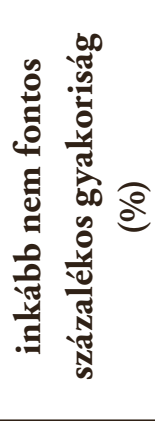 & 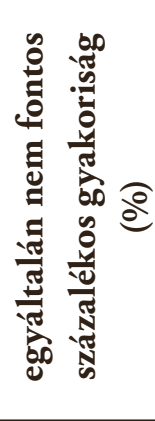 \\
\hline $\begin{array}{l}\text { az egyetemmel } \\
\text { való kutatási } \\
\text { együttmüködés }\end{array}$ & 67,6 & 28,4 & 3 & 1 \\
\hline $\begin{array}{l}\text { a pedagógusok } \\
\text { részvétele ped.-i és } \\
\text { pszich,-i kutatásokban }\end{array}$ & 57,8 & 36,3 & 6 & 0 \\
\hline $\begin{array}{l}\text { pedagógusok részvétele } \\
\text { tudományterületi } \\
\text { kutatásokban }\end{array}$ & 43,1 & 49 & 8 & 0 \\
\hline
\end{tabular}

\subsection{4. táblázat: A kutatás mint a gyakorlóiskola feladatának a megítélése}

A válaszadók kicsit kevesebb mint fele mind a három területet fontosnak tartja (24. táblázat). A három kategória vonatkozásában megvizsgáltuk azok arányát is, akik az egyáltalán nem vagy inkább nem válaszokat részesítették előnyben. Az egyáltalán nem válasz csak az egyetemmel való együttmüködésnél volt jelen, de ott is csak $1 \%$ tette erre a voksát. Itt az egyáltalán nem és inkább nem fontos válaszok együttes aránya 4\% volt. A pedagógusok pedagógiai és pszichológiai kutatásokban való részvételét $6 \%$, tudományterületi kutatásokba való bekapcsolódást pedig $8 \%$ nem tartotta fontosnak.

Tovább árnyalja a képet, hogy a gyakorlóiskola eredményességének a növeléséhez (Véleménye szerint az alábbi tényezök közül melyek segitik elö a leginkább az iskola eredményességének növekedését? Több választ is megjelölhet.) a pedagógusok motiváltságát (átlag = 0,78) és szakmai felkészültségét, képzettségét (átlag = 0,72) tartják elsősorban szükségesnek. Az egyetemmel való szoros együttműködés csak a hetedik a rangsorban (átlag = 0,27).

Következtetésképpen fogalmazhatjuk meg, hogy az iskola fejlődése szempontjából 
a pedagógusok mindenképpen a saját humánerőforrásuk fejlesztésében hisznek (pedagógiai és szaktudományi tudás). Kevésbé hisznek a kutatások által biztosított szakmai innovációk fontosságában.

A szakmai fejlesztő iskolává váláshoz fontos, hogy a gyakorlóiskola pedagógusai bekapcsolódjanak a helyi, az egyetemmel végzett kutatásokba. (Ön az elmúlt 5 évben bekapcsolódott valamilyen, az iskolában folyó kutatásba? igen, egy kutatásba; igen, több kutatásba is; nem vettem részt ilyen kutatásban). Jelentős többségben vannak a tantestületen belül (25. táblázat, lásd Melléklet), akik nem vettek részt kutatásokban (megjelölte =61,8\%). 21,6\% vett részt egy és 16,7\% több kutatásban. Ennek egyik oka lehet, hogy a pedagógusok nincsenek megfelelő kutatásmódszertani ismeretek birtokában. Mivel a kérdőív kitöltői nagyon sokan nem jelölték meg az iskolában eltöltött időt, beosztást és a pedagóguskategóriákat, így nagy ívü következtetéseket nem tudunk levonni arra vonatkozóan, hogy milyenek a csoportok közötti különbségek. A válaszadók közül azonban látható, hogy tipikus tendenciák érvényesülnek, azaz a legtöbb ideje az iskolában dolgozók, a mesterpedagógus fokozatban lévők és a szaktanácsadó vagy szakértő tanárok azok, akik a leginkább bekapcsolódtak valamilyen iskolai kutatásba.

Kicsit több mint egyharmada a pedagógusoknak vett részt közös kutatásokban (megjelölte $=38,3 \%$ ), és ez adat valójában ellentmondásban vannak azokkal, amelyek a kutatás fontosságát mutatják be a pedagógusok szemszögéből a gyakorló életében. A kutatásban való viszonylag alacsony részvétel magyarázatát adhatja egy másik fontos tényező, mégpedig az, hogy a pedagógusok szerint mennyire hasznosultak ezek a kutatási eredmények a gyakorlóiskola fejlesztésében (Ha az elözö kérdésre igennel válaszolt, véleménye szerint milyen mértékben sikerült felhasználni a kutatás eredményeit a gyakorlóiskola fejlesztéséhez? nem vett részt kutatásokban, egyáltalán nem sikerült, kis mértékben, közepes mértékben, nagy mértékben).

\begin{tabular}{|l|c|c|}
\hline $\begin{array}{l}\text { kategóriák } \\
\mathbf{N}=\mathbf{1 0 2}\end{array}$ & $\begin{array}{c}\text { hasznosság/gyakoriság } \\
\text { (fö) }\end{array}$ & $\begin{array}{c}\text { százalékos gyakoriság } \\
\text { (\%) }\end{array}$ \\
\hline $\begin{array}{l}\text { nem vett részt } \\
\text { kutatásokban }\end{array}$ & 63 & 61,8 \\
\hline egyáltalán nem sikerült & 4 & 3,9 \\
\hline kis mértékben & 10 & 9,8 \\
\hline közepes mértékben & 16 & 15,7 \\
\hline nagymértékben & 9 & 8,8 \\
\hline összes & 102 & 100 \\
\hline
\end{tabular}

8.26. táblázat: A közös kutatások hasznosságának megítélése 
Látható, hogy a pedagógusok igen megosztottak ezen a téren (26. táblázat). Arányaiban a közepes mértékủ hasznosulás mellett teszik le a legtöbben a voksukat, de nem tekinthetünk el azoktól a véleményektől, amelyek szerint kicsi volt a hasznosulás mértéke, vagy egyáltalán nem hasznosultak az eredmények. Ezt támasztják alá azok az elemzések is, amelyek a háttérváltozók (iskolában eltöltött év, beosztás és fokozat) mentén próbáltak feltárni bizonyos eltéréseket a válaszadók csoportjai között. A közepes mértékủ hasznosulás véleményén elsősorban a 21-30 éve az iskolában dolgozók, a szakértők és szaktanácsadók, és a mesterpedagógus fokozatban lévők vannak. Itt vissza kell térnünk a fejezet elején vizsgált kérdéskörre, vagyis az egyetem és a gyakorlóiskola együttműködése az iskola eredményességének növekedésében a pedagógusok szerint inkább a pedagógusok pedagógiai és szaktudományos tudását hivatott fejleszteni. A közös kutatások eredményeivel kapcsolatban megfogalmazott kételyek itt támasztják alá, hogy az iskola eredményességének a növelésében miért nem tulajdonítanak fontos szerepet a közös kutatásoknak.

Összegzésképpen tehát elmondható, hogy a kutatásokba való bekapcsolódást az iskola szakmai fejlesztő iskolává válásában fontosnak tartják a pedagógusok, ugyanakkor kicsit több mint egyharmaduk vett csak részt ezekben a kutatásokban, a kutatásmódszertani ismeretek hiánya és az eredmények hasznosulásával kapcsolatos kétségeik magyarázatot adhatnak az alacsony részvétel okaira. Harmadik hipotézisünk nem nyert alátámasztást. Bár a gyakorlóiskola fejlesztő iskolává válásában a pedagógusok fontosnak tartják az egyetemmel közösen végzett kutatásokat, ez a ténylegesen a kutatásokba bekapcsolódó pedagógusok számában nem tükröződik.

Még egy szempontot érdemes itt megvizsgálnunk. Azok, akik bekapcsolódtak az egyetemmel közös kutatásokba, mennyire elégedettek az egyetemi oktatókkal való együttmüködéssel (Kérjük, határozza meg, hogy Ön mennyire elégedett az alábbi tényezökkel! „1 = egyáltalán nem vagyok elégedett”, „2 = inkább nem vagyok elégedett”, ,3 = elégedett is vagyok, meg nem is”, „4 = inkább elégedett vagyok”, ,5 = teljes mértékben elégedett vagyok” és Ön az elmúlt 5 évben bekapcsolódott valamilyen az iskolában folyó kutatásba? igen, egy kutatásba; igen, több kutatásba is; nem vettem részt ilyen kutatásban). Azok, akik több kutatásban vettek részt, azoknak a negyed része (megjelölte $=25,02 \%$ ), akik pedig egy kutatásban vettek részt, kevesebb mint egy negyed része (megjelölte $=20,02 \%$ ) elégedett az egyetemi oktatókkal való együttmüködéssel (27. táblázat, lásd Melléklet).

Érdemes elemeznünk az egyetemi oktatók véleményét is ebben a kérdésben (Kérjük, értékelje az alábbi felsorolt célokat abból a szempontból, hogy Ön szerint melyek lehetnek a gyakorlóiskola legfontosabb feladatai! 1 = nem fontos ... 5 = nagyon fontos). Az oktatók a hallgatók színvonalas felkészítését tartják a legfontosabb gyakorlóiskolai feladatnak (átlag = 5). Az egyetemmel való kutatási együttműködés csak kilencedik a rangsorban (átlag = 3,92). A pedagógusok részvétele pedagógiai, pszichológiai témájú kutatásokban 
(átlag = 3,5) és szaktudományi kutatásokban (átlag = 3,25) csak ezután kerül megnevezésre (28. táblázat, lásd Melléklet).

A gyakorlóiskola egyetemmel való együttműködésével a kutatásban, fejlesztésben való részvétel esetében a 3,38-as átlag közepes elégedettséget jelez az oktatók részéről (Mennyire itéli eredményesnek az együttmüködést? "1 = egyáltalán nem vagyok elégedett”, „2 = inkább nem vagyok elégedett”, „3 = elégedett is vagyok, meg nem is”, „4 = inkább elégedett vagyok”, „5 = teljes mértékben elégedett vagyok”, 29. táblázat, lásd Melléklet), még kisebb ez az érték a kutatások, fejlesztések tervezése (átlag = 3,13) és a publikációk készítése területén (átlag = 2,83). Sorrendileg a három részterület a 17 kategóriából a 13., 16. és 17. helyet foglalja el. Ez azt mutatja, hogy az oktatók véleménye szerint a gyakorlóiskola pedagógusai nem lépnek fel mint aktív kezdeményezők a gyakorlati problémák megoldásához vezető magasabb szintű reflektivitás dimenziójának megvalósításáért.

\subsubsection{A gyakorlóiskola és a hallgatók}

Az egyetem és a gyakorlóiskola együttmüködését a szakmai fejlesztés vonatkozásában érdemes megvizsgálni a hallgatók szempontjából is. A hallgatók bár kevesen töltötték ki a kérdőívet (22 fó), az ötfokozatú Likert-skálán mért adatok alapján (30. táblázat, lásd Melléklet) nem igazán elégedettek az egyetemi képzés és az iskolai gyakorlatok közötti tartalmi összhanggal (átlag = 2,89), ami felveti az egyetem és a gyakorlóiskola együttműködésének a hiányosságait (Kérjük, jelölje meg, hogy mennyire elégedett az alábbiakkal! 1 = egyáltalán nem értek egyet, 2 = inkább nem éretek egyet, 3 = egyet is értek meg nem is, 4 = inkább egyet értek, 5 = teljes mértékben egyetértek). A saját pedagógiai és pszichológiai felkészültségüket (átlag $=4,11$ ) és szaktárgyi felkészültségüket (átlag = 4,05) jó színvonalúnak ítélik meg. A módszertani felkészültségüket kissé alacsonyabbra értékelik (átlag = 3,94). A válaszadók szerint az egyetemi kurzusok (31. táblázat, lásd Melléklet) a szakmai tudáson belül a munkaformák (16 fó), a szaktárgyi tudás (12 fó), a pedagógiai tudás (11 fö), a tanári önreflexió (10fó), a pszichológiai tudás (10 fó) és a szakmódszertani tudás (10 fö) vonatkozásában adják a legtöbbet a tanári professzióra való felkészülésben (Mely területeken biztositották leginkább az egyetemi kurzusok a tanári professzióra való felkészülést? Legfeljebb öt válasz megjelölése). A kollégákkal való együttmüködés (0 fö), a felzárkóztatás (1 fö), az osztályfönöki feladatok (1fó), a szülőkkel való együttműködés (1 fó), a fegyelmezés (1 fö) területein a válaszadók közül igen kevesen kapnak felkészítést. A gyakorlóiskola (32. táblázat, lásd Melléklet) az óravezetés (16 fó), a munkaformák (15 fö), a szakmódszertani tudás (15 fó), a pedagógiai tervezés (13 fó) területén készíti leginkább fel a hallgatókat a pályára. Hiánynak érzik a szülőkkel való együttműködés (0 fó) és az osztályfőnöki feladatok (1 fơ) területein való felkészítést (Mely területeken biztositották leginkább a gyakorlóiskolai feladatok a tanári professzióra 
való felkészülést? Legfeljebb öt válasz megjelölése). Azok a válaszadók, akik alacsonyra értékelik az egyetemi képzés és a gyakorlóiskola tartalmi összhangját, a leggyakrabban az egyetemi képzés gyakorlatorientáltságát nevezik meg hiányként (8fó). A hallgatók bizonyos szervezésből adódó ütközéseket is megemlítenek, pl. a módszertani gyakorlat később van az egyetemen, mint a gyakorlóban, vagy ütköznek a hallgató órarendjében az egyetemi órák és a gyakorlóiskolai feladatok.

Szembetűnően alacsony a hallgatók együttműködése a gyakorlóiskola más szaktanáraival. A 22 válaszadóból 1 fó vett részt tantestületi (33. táblázat, lásd Melléklet), 1 fó munkaközösségi megbeszélésen (Részt vett Ön az iskolai gyakorlatai során nevelötestületi értekezleten? Igen, Nem; Részt vett Ön az iskolai gyakorlatai során munkaközösségi megbeszélésen? Igen, Nem). Vagyis a gyakorlóval való kapcsolatot a pedagógusok vonatkozásában csakis a szakvezető jelenti a hallgatóknak.

A kérdőív nyílt kérdésére adott válaszai alapján összehasonlítható a gyakorlóiskolai tevékenység és a féléves tanítási gyakorlat (Miben látja a leglényegesebb különbséget az egri tanitási gyakorlat és a féléves tanitási gyakorlat között?). A hallgatók a gyakorló mellett sorolnak fel olyan érveket, mint a részletes, dokumentált óratervezés, a diákok jó fegyelmi helyzete és motiváltsága, a szakvezető módszertani felkészültsége. Ugyanakkor igen sok pozitív elemet neveznek meg a féléves tanítási gyakorlatukra vonatkozóan is felismerve a két gyakorlat közötti funkcionális különbséget: nagyobb önállóság, több fejlődési lehetőség, több idő a diákokkal való kapcsolat alakítására, több lehetőség az iskola mint intézmény megismerésére.

A hallgatók nézeteinek vizsgálata alapján megállapítható, hogy a gyakorlóiskola és benne a magas szakmai színvonalat képviselő szakvezető nagyon fontos szerepet játszik a tanári professzióra való felkészítésben. Alátámasztást nyert negyedik hipotézisünk, amelyik szerint a gyakorlóiskolai pedagógusok magas szintü szakmai tudása és a pálya iránti elkötelezettsége hat a hallgatók nézeteire. A gyakorlóiskolai jelenlét elsősorban a tanóra keretein belüli gyakorlati tapasztalatok szerzését biztosítja a hallgatóknak. Hiányként jelenik meg a szélesebb szakmai kontextusba való bekapcsolódás biztosítása a hallgató számára a szakmai fejlesztés vonatkozásában. Ötödik hipotézisünk, azaz a pedagógusok törekszenek a tanárjelöltek bevonására az iskola szakmai önfejlesztő tevékenységébe elhivatottságuk növelése érdekében, nem nyert alátámasztást.

Szintén hiányként nevezhető meg az egyetem és a gyakorlóiskola összehangoltabb együttműködése mind tartalmi, mind szervezési oldalról. Korábban a pedagógusok nézeteit elemezve a 8.6. táblázat alapján azt a következtetést vontuk le, hogy a pedagógusok nem tulajdonítanak kiemelkedő szerepet az egyetem és a gyakorló együttműködésének (megjelölte $=5 \%$ ), a hallgatók nagyobb támogatásának (megjelölte $=4 \%$ ) a szakmai fejlesztő iskolává váláshoz. Mindez tetten érhető a hallgatók nézeteiben, többet várnak 
a gyakorlóiskolától: a tanórákra korlátozott szakmai tudás megosztása tanórán kívüli tudásmegosztássá való szélesítését. Ezért jövőbeli feladatként fogalmazható meg a hallgatóknak a tanítás szélesebb kontextusába való bevezetése, pl. pedagógus kollégákkal, szülőkkel való kapcsolattartás fejlesztése, fegyelmezési problémákra való felkészítés, valamint az egyetem és a gyakorlóiskola tartalmi és szervezési kérdésekben való nagyobb fokú kooperációja.

\section{5. Összegzés}

Tanulmányunkban a pedagógusok, oktatók és hallgatók nézeteit vizsgáltuk meg arra a kérdésre keresve a választ, hogy szakmai fejlesztés szempontjából mitől jó egy gyakorlóiskola. Hangsúlyozzuk, hogy az érdekelt felek nézeteit állítottuk vizsgálatunk fókuszába abból a célból, hogy feltérképezzük, egy gyakorlóiskolának a szakmai fejlesztő iskolává válásához milyen lépéseket szükséges megtenni a jövőben.

A rendelkezésre álló adatok alapján egyértelműen kijelenthető, hogy

1. az iskolavezetés és a pedagógusok is a szakmai fejlesztés és fejlődés elsődlegességét vallják, a magas szintü szakmai tudást elsősorban az iskolában tanuló gyermekek fejlesztése érdekében kívánják felhasználni,

2. a pedagógusok magasra értékelik szakmai tudásukat, és intenzíven tesznek is e tudás fejlesztéséért,

3. bár a gyakorlóiskola tudásmegosztó szerepének nem tulajdonítanak akkora jelentőséget, mint a más iskolák számára nyújtott példamutatásnak, mégis kiemelkedő a tudásmegosztásban részt vevők száma,

4. az egyetemmel való együttműködést és a hallgatók támogatását kevésbé tartják fontosnak a pedagógusok, az egyetemmel való közös kutatások eredményeinek a megítélése nem egyértelmüen pozitív, viszonylag kevesen vesznek részt ilyen kutatásokban, inkább saját szakmai tudásuk fejlesztésében kamatoztatják az egyetemmel való kooperációt,

5. a gyakorlóiskolai pedagógusok magas szintű szakmai tudása és a pálya iránti elkötelezettsége nagymértékben hatással van a hallgatók nézeteire, ugyanakkor a hallgatók többet várnak az egyetemtől és a gyakorlóiskolától: kedvezőbb lenne számukra, ha a képzés tartalmi és szervezési vonatkozásában hatékonyabb egyeztetés valósulna meg a két intézmény között, másrészt a gyakorlóiskolai, a tanórára fókuszáló képzést szeretnék kitágítani az egész iskolára és az iskolai környezetre is. 


\section{Javaslatok}

A szakmai fejlesztő iskolává válásához javaslatként fogalmazzuk meg a fenntartó és az iskolavezetés számára:

1. az egyetem és az iskola szélesebb körű együttműködésének ösztönzését mind a két intézmény, mind pedig az intézményekben dolgozó pedagógusok és oktatók között,

2. az egyenrangú partneri viszony erősítését a hétköznapi kommunikációtól egészen a közösen végrehatott kutatásokkal bezárólag;

az iskolavezetés számára:

1. a hallgatók tanári professzióra való felkészítéséhez a gyakorlóiskolai mozgásterük kiszélesítését, a szakmai önfejlesztés perspektíváinak hatékonyabb bemutatását és annak megvalósítását,

2. a hallgatói visszacsatolások beépítését gyakorlati képzésük fejlesztésébe,

3. a gyakorlati problémák megoldását, és innovációk támogatását ösztönző kutatások felkarolását és az ehhez nélkülözhetetlen kutatás módszertani képzések erősítését a pedagógusok számára;

a pedagógusok számára:

1. az egyetem irányában a hallgatók képzésével kapcsolatos problémák megoldására a kezdeményező szerep felvállalását, konkrétabban a problémák kommunikálását a megfelelő tanszékek irányába,

2. a hallgatók intenzívebb bevonását az iskolában megvalósított szakmai fejlesztési programokba, tantestületi, munkaközösségi szinten megjelenő önfejlesztő tevékenységekbe;

az oktatók számára:

1. az általános pszichológiai, pedagógiai, valamint szakmódszertani és szaktudományi területeken dolgozó oktatók aktívabb kapcsolatteremtését a gyakorlóiskola pedagógusaival képzési és kutatási területeken,

2. a hallgatók elméleti és gyakorlati képzésében felmerülő problémák hatékonyabb észlelését és kommunikálását a megfelelő tanszékek irányában. 


\section{Felhasznált irodalom:}

Borko, H. és Putnam, R. T. (1995): Expanding a teacher's knowledge base: a cognitive psychological perspective on professional development, in Guskey, T. R. és Huberman, M.: Professinal development in education: new paradigms and practices, Teachers College Press, New York.

Cochran-Smith, M. és Lytle, S. L. (2001): Beyond ceratinty: taking an iquiry Teachers caught in the action, professional development that matters. Teachers College Press, New York.

Darling-Hammond, L. (1994): Professional Development Schools: Schools to develop profession, Teacher College Press, New York.

Darling-Hammong, L. és McLaughlin, M. W. (1995): Policies that support professional development in an era of reform, in Phi Delta Kappan, 76 (8), 597-604.

Dreyfus, H. L. és Dreyfus, S. E. (1986): Mind over machine, Free Press, New York.

Falus Iván (2001): A gyakorlat pedagógiája. In: Golnhofer Erzsébet és Nahalka István (szerk.): A pedagógusok pedagógiája. Nemzeti Tankönyvkiadó, Budapest. 15-27.

Glatthorn, A. (1990): Supervisory leadership, Scott Foresman, Illiois, Glenview.

Grace, D. (1999): Paradigm lost (and reagined) in Indpendent School 59 (1), 54-57.

Gorski, P., Shin, G. T. és Green, M. (2000): Professional development guide for educatiors (The Multicultural Resource Series, Volume 1) National Education Association of the USA, Washington, D. C.

Guskey, J. L. (1995): Professional development in education: in search if the optional mix, in Guskey, T. R., Huberman, M.: Professional development in education: New paradigms and practices. Teachers College Press, New York.

Guskey, J. L. (1997): Research needs to link professional development and student learning, Journal of Staff Development, 18, 36-40.

Kotschy Beáta (2003): Szakmai fejlesztő/fejlödő iskolák - a pedagógusképzés megújításának egy lehetősége, Pedagógusképzés 1. évf. 1-2. sz 109-117.

Little, J. W. (2001): Professional development in pursuit of school reform, in Lieberman, A. és Miller, L.: Teachers caught in the action, Professional developmet that matters, Teachers College Press, New York.

National Council for the Accreditation of Teacher Education (2016): Professional Development Schools, http://www.ncate.org/ProfessionalDevelopmentSchools/tabid/ 497/Default.aspx Letöltve: 2017. február 10.

Pianfetti, E. S. (2001): Teachers and technology: digital literacy through professional development, Language Arts, 78 (3), 255-262. 
Romerdahl, N. és Gehrke, N. (1993): The shared leadership in teacher leaders and principals in professional development schools. Paper presented at the annual meeting of the AERA, Atlanta.

Schifter, D., Russel, S. J. és Bastable, V. (1999): Teacing to the big ideas, in Solomon, M. Z. (szerk.) The diagnostic teacher: constructing new approaches to professional development, Teachers College Press, New York.

Teitel, L. (2004): Two Decades of Professional Development School Development in the United States. What Have We Learned? Where Do We Go from Here?, Journal of Inservice Education, 30, Number 3. https://doi.org/10.1080/13674580400200335

Villegars-Reimers, E. és Reimers, F. (1996): Where are 60 million teachers? The missing voice in educational reforms around the world, Prospects, 26 (3), 469-494. https://doi.org/10.1007/BF02195052

Villegas-Reimers, E. (2003): Teacher Professional Development: an international review of the literature, UNESCO: International Institute for Educational Planning, http://unesdoc. unesco.org/images/0013/001330/133010e.pdf, letöltve: 2017. március 15.

Wood, F. és McQuarrie, F. (1999): On-the-job learning, Journal of Staff Development, 20 (3), 10-13.

Zagyváné Szűcs Ida (2016): Elkötelezettség és felelősségvállalás a szakmai fejlődésért, in Zsolnai Anikó, Kasik László (szerk.): A tanulás és nevelés interdiszciplináris megközelitése: XVI. Országos Neveléstudományi Konferencia. 497 p. 


\section{Melléklet:}

\begin{tabular}{|l|c|c|}
\hline $\begin{array}{l}\text { kategóriák } \\
\mathbf{N}=\mathbf{1 0 2}\end{array}$ & átlag & szórás \\
\hline a pedagógus módszertani tudásának fejlesztése & 0,52 & 0,502 \\
\hline tanulók kompetenciáinak fejlesztése & 0,50 & 0,502 \\
\hline tehetséggondozás fejlesztése & 0,47 & 0,502 \\
\hline a pedagógus IKT-kompetenciájának fejlesztése & 0,35 & 0,480 \\
\hline a tanulók tanulmányi teljesítményének fejlesztése & 0,32 & 0,470 \\
\hline
\end{tabular}

8.1. táblázat: A szakmai fejlődés preferált területei az iskolavezetés által

\begin{tabular}{|c|c|c|c|c|c|}
\hline $\begin{array}{l}\text { kategóriák } \\
\mathrm{N}=102\end{array}$ & 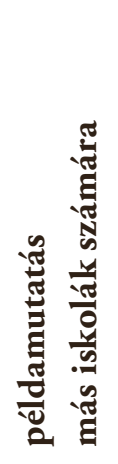 & 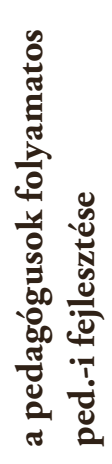 & 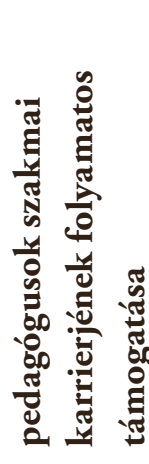 & 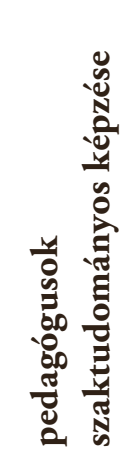 & 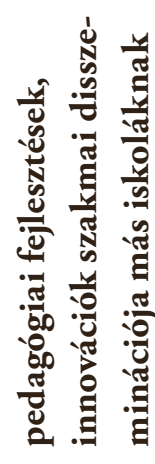 \\
\hline átlag & 4,55 & 4,42 & 4,22 & 4,17 & 4,15 \\
\hline szórás & 0,684 & 0,696 & 0,712 & 0,785 & 0,813 \\
\hline $\begin{array}{l}\text { kategóriák } \\
\mathrm{N}=102\end{array}$ & 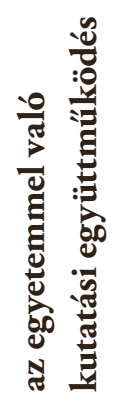 & 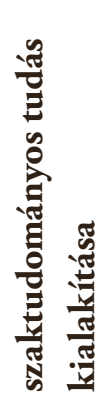 & \multicolumn{2}{|c|}{ 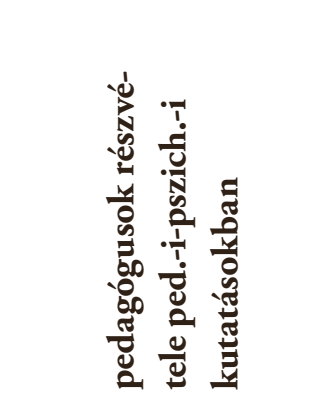 } & 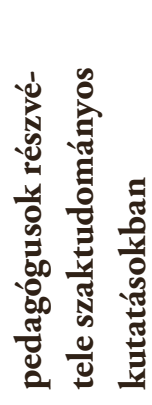 \\
\hline átlag & 3,86 & 3,78 & \multicolumn{2}{|c|}{3,72} & 3,45 \\
\hline szórás & 0,845 & 0,791 & \multicolumn{2}{|c|}{0,849} & 0,779 \\
\hline
\end{tabular}

8.4. táblázat: A gyakorlóiskola legfontosabb feladatai a pedagógusok szerint 


\begin{tabular}{|c|c|c|}
\hline $\begin{array}{l}\text { a pedagógusok } \\
\text { szerint az iskola által } \\
\text { legfontosabbnak tartott } \\
\text { fejlesztési területek } \mathrm{N}=95\end{array}$ & $\begin{array}{l}\text { a pedagógusok által fejleszteni } \\
\text { kívánt saját szakmai területek }\end{array}$ & $\begin{array}{c}\text { mindkét } \\
\text { kategóriánál } \\
\text { az igen } \\
\text { válaszok/ } \\
\text { gyakoriság (fó) }\end{array}$ \\
\hline $\begin{array}{l}\text { a pedagógusok módszertani } \\
\text { tudásának fejlesztése }\end{array}$ & szakmódszertani tudás & 20 \\
\hline $\begin{array}{l}\text { a tanulók kompetenciáinak } \\
\text { fejlesztése }\end{array}$ & IKT-kompetenciák & 19 \\
\hline $\begin{array}{l}\text { a tanulók kompetenciáinak } \\
\text { fejlesztése }\end{array}$ & idegen nyelvi kompetenciák & 16 \\
\hline tehetséggondozás & tehetséggondozás & 14 \\
\hline $\begin{array}{l}\text { a pedagógusok } \\
\text { IKT-kompetenciáinak fejlesztése }\end{array}$ & IKT-kompetenciák & 13 \\
\hline $\begin{array}{l}\text { a tanulók tanulmányi } \\
\text { munkájának javítása }\end{array}$ & $\begin{array}{l}\text { nevelést segítő módszertani } \\
\text { tudás }\end{array}$ & 13 \\
\hline $\begin{array}{l}\text { a tanulók tanulmányi } \\
\text { munkájának javítása }\end{array}$ & $\begin{array}{l}\text { különleges bánásmódot igénylő } \\
\text { gyermekek fejlődésének } \\
\text { támogatása }\end{array}$ & 12 \\
\hline $\begin{array}{l}\text { a tanulók tanulmányi } \\
\text { munkájának javítása }\end{array}$ & IKT-kompetenciák & 11 \\
\hline $\begin{array}{l}\text { a tanulók tanulmányi } \\
\text { munkájának javítása }\end{array}$ & tehetséggondozás & 8 \\
\hline $\begin{array}{l}\text { a tanulók tanulmányi } \\
\text { munkájának javítása }\end{array}$ & szakmódszertani tudás & 8 \\
\hline $\begin{array}{l}\text { a tanulók neveltségi szintjének } \\
\text { emelése }\end{array}$ & $\begin{array}{l}\text { nevelést segítő módszertani } \\
\text { tudás }\end{array}$ & 4 \\
\hline $\begin{array}{l}\text { a tanulók IKT-kompetenciáinak } \\
\text { fejlesztése }\end{array}$ & IKT-kompetenciák & 3 \\
\hline $\begin{array}{l}\text { a művészeti nevelés } \\
\text { színvonalának emelése }\end{array}$ & művészeti nevelés & 2 \\
\hline $\begin{array}{l}\text { a tanulók tanulmányi } \\
\text { munkájának javítása }\end{array}$ & diszciplináris tudás & 2 \\
\hline $\begin{array}{l}\text { tanárjelöltek szakmai } \\
\text { fejlődésének segítése }\end{array}$ & mentorálás & 2 \\
\hline idegen nyelvi képzés & idegen nyelvi kompetenciák & 2 \\
\hline
\end{tabular}




\begin{tabular}{|l|l|c|}
\hline $\begin{array}{l}\text { a pedagógusok } \\
\text { legfontosabbnak tartott } \\
\text { fejlesztési területek N = 95 }\end{array}$ & $\begin{array}{l}\text { a pedagógusok által fejleszteni } \\
\text { kívánt saját szakmai területek }\end{array}$ & $\begin{array}{c}\text { mindkét } \\
\text { kategóriánál } \\
\text { az igen } \\
\text { válaszok/ } \\
\text { gyakoriság (fó) }\end{array}$ \\
\hline $\begin{array}{l}\text { pedagógusok felkészítése helyi } \\
\text { kutatásokra }\end{array}$ & kutatásmódszertani tudás & 2 \\
\hline $\begin{array}{l}\text { különleges bánásmódot igénylö } \\
\text { gyermekek fejlesztése }\end{array}$ & $\begin{array}{l}\text { különleges bánásmódot igénylö } \\
\text { gyermekek fejlődésének } \\
\text { támogatása }\end{array}$ & 1 \\
\hline környezeti nevelés & környezeti nevelés & 1 \\
\hline $\begin{array}{l}\text { a pedagógusok diszciplináris } \\
\text { tudásának fejlesztése tudása }\end{array}$ & diszciplináris tudás & 1 \\
\hline
\end{tabular}

8.5. táblázat: Az iskolavezetés és a pedagógusok által legfontosabbnak tartott szakmai területek

\begin{tabular}{|c|c|c|c|c|c|}
\hline \multirow{2}{*}{$\begin{array}{l}\mathrm{N}=113 \\
\text { kategória }\end{array}$} & \multicolumn{5}{|c|}{ százalékos gyakoriság (\%) } \\
\hline & 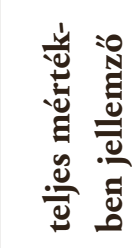 & 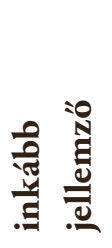 & 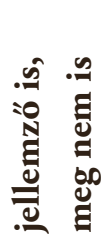 & 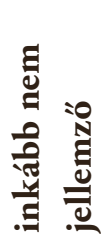 & 苞 \\
\hline $\begin{array}{l}\text { kiváló szakmai tudással } \\
\text { rendelkezem }\end{array}$ & 38,9 & 53,31 & 7,1 & 0,9 & 0 \\
\hline $\begin{array}{l}\text { keresem a folyamatos } \\
\text { megújulás lehetőségeit }\end{array}$ & 45,1 & 40,7 & 13,3 & 0,9 & 0 \\
\hline $\begin{array}{l}\text { nyomon követem } \\
\text { a szakirodalmat }\end{array}$ & 19,5 & 44,2 & 31,9 & 3,5 & 0,9 \\
\hline $\begin{array}{l}\text { szívesen tartanék } \\
\text { mühelyfoglalkozásokat }\end{array}$ & 23,9 & 26,5 & 20,4 & 15,9 & 13,3 \\
\hline $\begin{array}{l}\text { szívesen tartanék } \\
\text { bemutatóórákat }\end{array}$ & 18,6 & 28,3 & 25,7 & 16,8 & 10,6 \\
\hline
\end{tabular}

8.7. táblázat: A pedagógusok önértékelése szakmai tudásuk és önfejlesztésük vonatkozásában 


\begin{tabular}{|l|l|l|}
\hline $\begin{array}{l}\text { kategória } \\
\mathbf{N}=\mathbf{1 0 2}\end{array}$ & átlag & szórás \\
\hline IKT-kompetenciák & 44 & 499 \\
\hline $\begin{array}{l}\text { különleges bánásmódot } \\
\text { igénylő tanulók fejlődésé- } \\
\text { nek támogatása }\end{array}$ & 41 & 495 \\
\hline szakmódszertani tudás & 33 & 474 \\
\hline $\begin{array}{l}\text { nevelést segítő módszertani } \\
\text { tudás }\end{array}$ & 33 & 474 \\
\hline idegen nyelvi kompetencia & 26 & 443 \\
\hline $\begin{array}{l}\text { általános ped.-i és pszich.-i } \\
\text { tudás }\end{array}$ & 17 & 375 \\
\hline
\end{tabular}

\section{8. táblázat: A leginkább fejlesztésre váró területek a szakmai önfejlesztés területén}

\begin{tabular}{|l|l|l|}
\hline kategóriák N = 102 & átlag & szórás \\
\hline szakmai folyóiratokat, könyvet olvas & 0,86 & 0,346 \\
\hline más tantestületek, szakmai közösségek adatbázisát használja & 0,37 & 0,486 \\
\hline a kollégák óráit látogatja, megbeszélik a tapasztalatokat & 0,31 & 0,466 \\
\hline tantestület szakmai adatbázisa & 0,28 & 0,453 \\
\hline az egyetem által szervezett konferenciákra jár & 0,28 & 0,453 \\
\hline szakkönyvtárba jár & 0,27 & 0,448 \\
\hline hazai konferenciákra jár & 0,27 & 0,448 \\
\hline iskolai könyvtárba jár & 0,25 & 0,438 \\
\hline publikál szakmai témákról & 0,07 & 0,254 \\
\hline saját vagy közös tanári weboldalt múködtet & 0,05 & 0,217 \\
\hline nemzetközi konferenciákra jár & 0,01 & 0,99 \\
\hline blogot ír & 0 & 0 \\
\hline
\end{tabular}

\section{9. táblázat: A szakmai önfejlesztés pedagógusok által előnyben részesített lehetőségei}




\begin{tabular}{|c|c|c|c|c|c|c|c|c|c|c|c|}
\hline \multirow{9}{*}{ 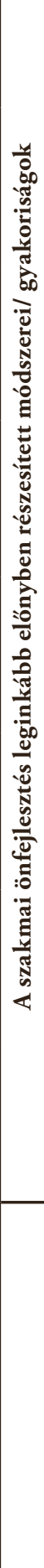 } & összes & $\bar{\Xi}$ & $\hat{n}$ & กे & 옴 & 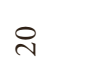 & $\infty$ & तิ & $\stackrel{\circ}{ \pm}$ & $\infty$ & $\infty$ \\
\hline & iskolai könyvtárba járok & $a$ & $v$ & $\sim$ & $\stackrel{n}{2}$ & - & $=$ & $n$ & 음 & $\infty$ & $\infty$ \\
\hline & $\begin{array}{r}\text { hazai konferenciákra } \\
\text { járok, amelyeket más } \\
\text { egyetemek, fóiskolák } \\
\text { szerveznek }\end{array}$ & $\cong$ & ๑ & n & \pm & $\sim$ & $\infty$ & N & 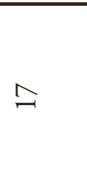 & $\wedge$ & \\
\hline & $\begin{array}{r}\text { használom a tantestület } \\
\text { adatbázisát }\end{array}$ & 으 & $\curvearrowright$ & n & $\Xi$ & 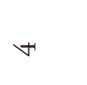 & 으 & $\checkmark$ & $\stackrel{\infty}{-1}$ & $\curvearrowleft$ & $n$ \\
\hline & $\begin{array}{r}\text { látogatom kollégáim } \\
\text { óráit, majd megbeszéljük } \\
\text { a tapasztalatokat }\end{array}$ & $\stackrel{\infty}{-}$ & a & t & $\stackrel{\bullet}{-}$ & N & $\infty$ & $n$ & $\bumpeq$ & $\exists$ & \\
\hline & $\begin{array}{r}\text { konferenciákra járok, } \\
\text { amelyeket az egyetem } \\
\text { vagy föiskola szervez }\end{array}$ & $\cong$ & $\infty$ & $n$ & 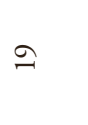 & $\sim$ & $\exists$ & N & $\stackrel{\odot}{\smile}$ & 으 & $\exists$ \\
\hline & $\begin{array}{l}\text { használom más } \\
\text { tantestületek, szakmai } \\
\text { közösségek adatbázisát }\end{array}$ & 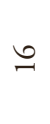 & $a$ & $n$ & $\stackrel{\infty}{-}$ & $n$ & $\stackrel{m}{=}$ & $\bullet$ & ㄱ. & $\beth$ & 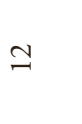 \\
\hline & $\begin{array}{r}\text { szakmai folyóiratokat, } \\
\text { könyveket olvasok }\end{array}$ & $\infty$ & $\smile$ & $\infty$ & 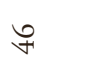 & $\bullet$ & તิ & $\wedge$ & $\stackrel{ }{+}$ & $\stackrel{\Downarrow}{\sim}$ & 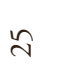 \\
\hline & 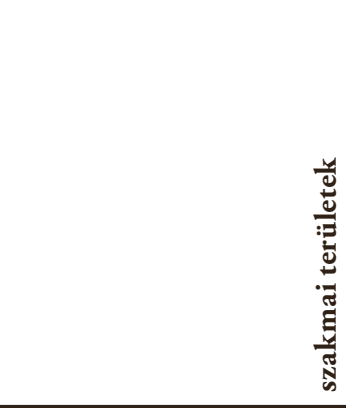 & 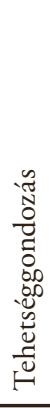 & 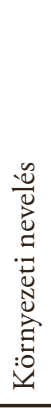 & 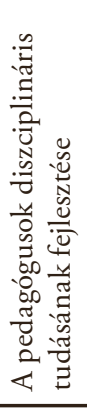 & 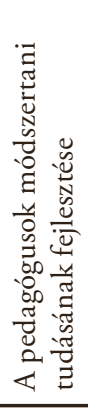 & 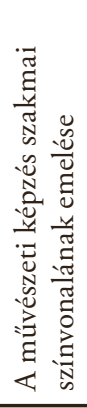 & 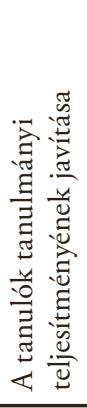 & 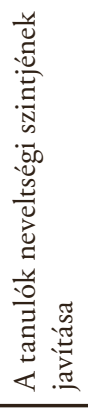 & 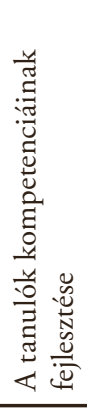 & 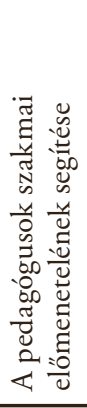 & 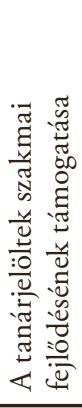 \\
\hline
\end{tabular}




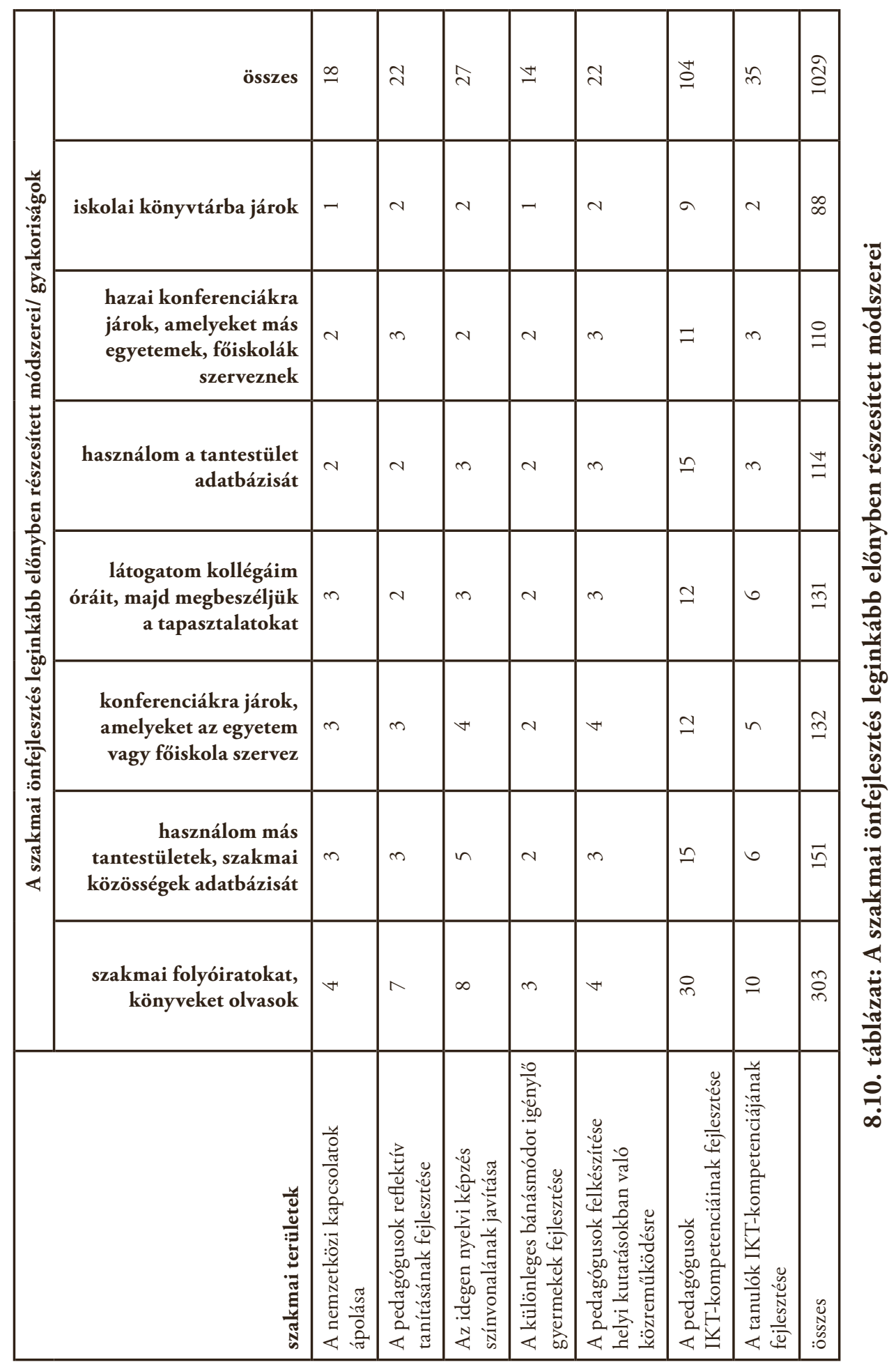




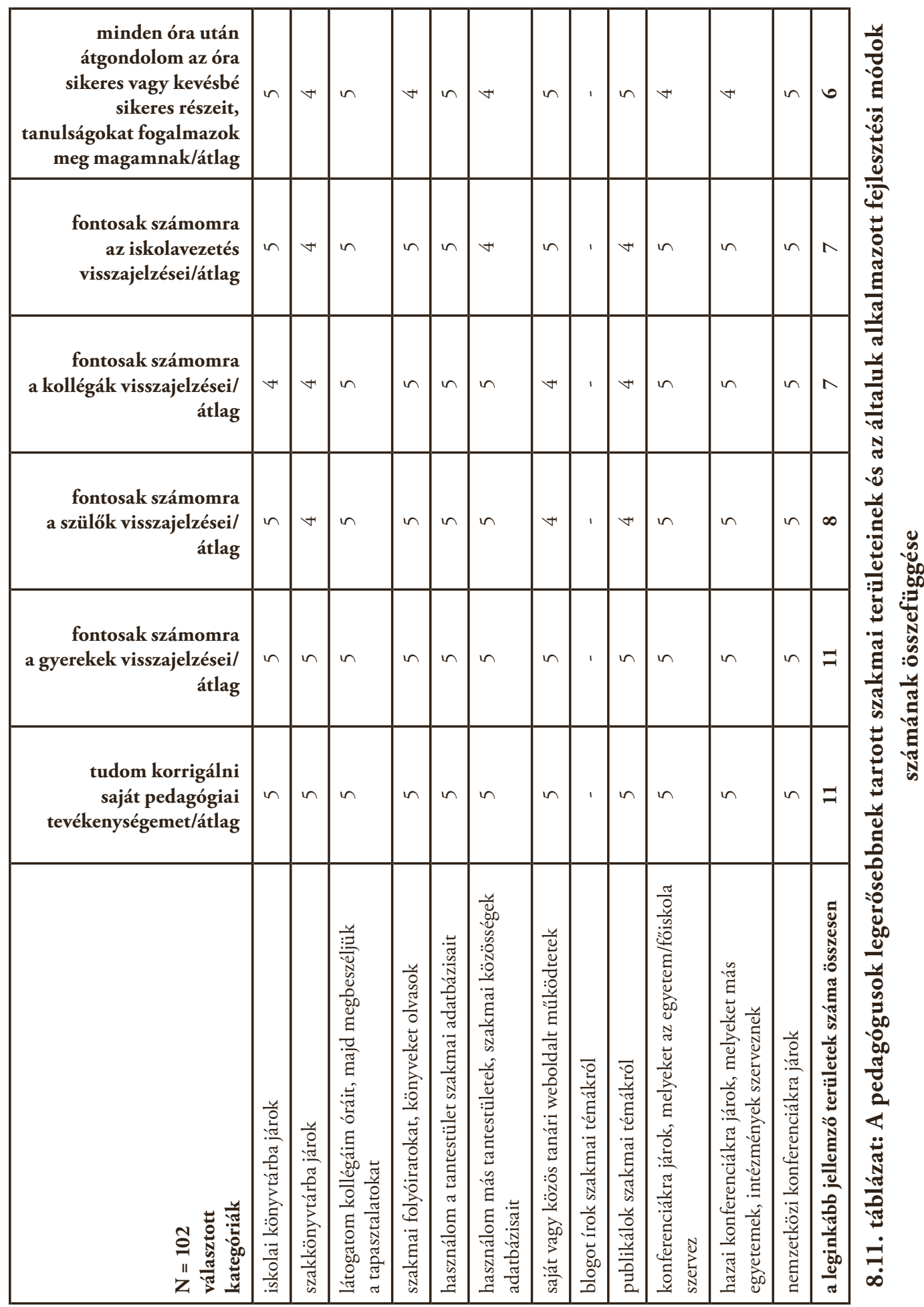




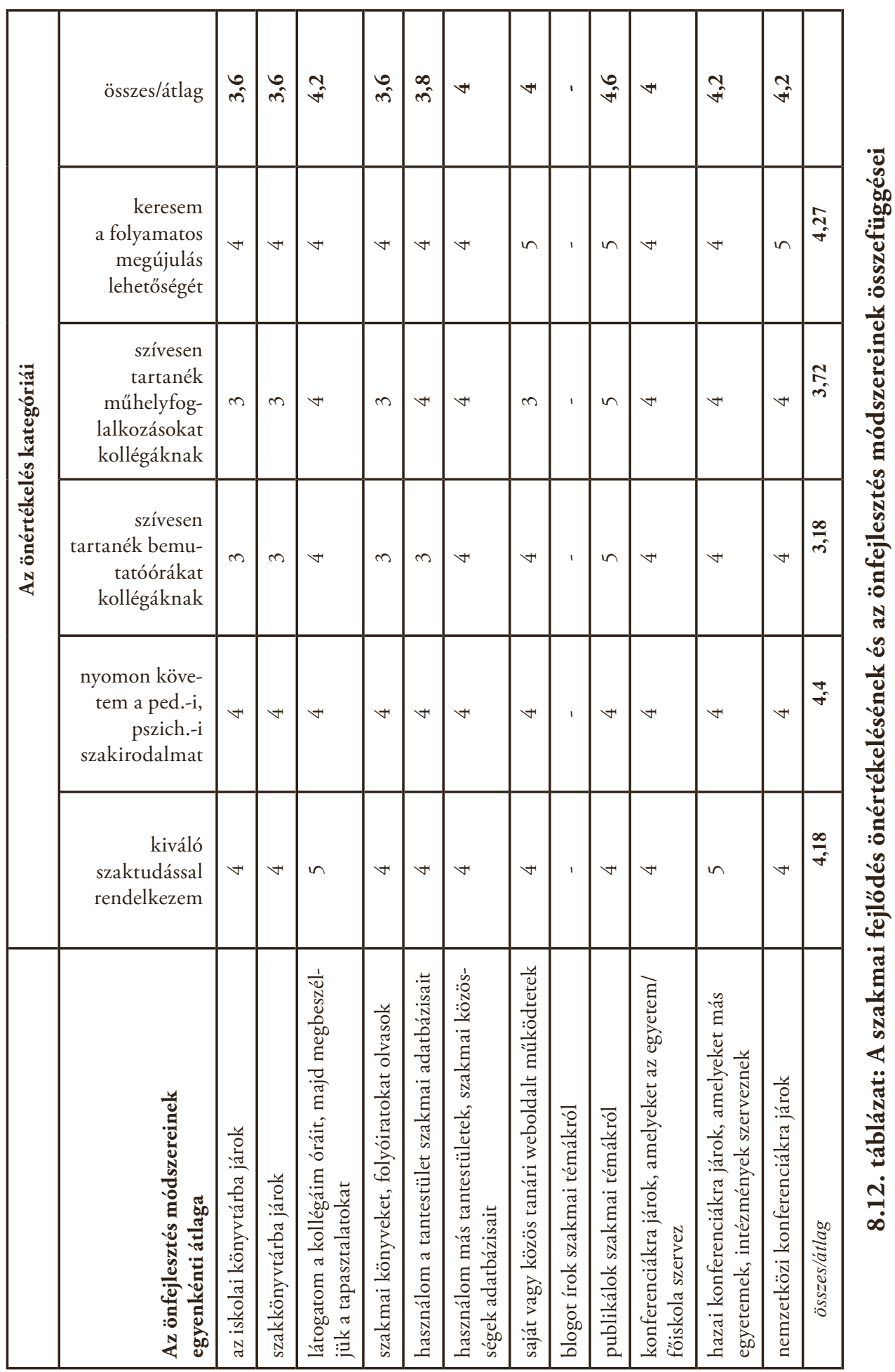




\begin{tabular}{|c|c|c|c|c|c|}
\hline \multirow{2}{*}{$\frac{\mathrm{N}=125}{\text { kategória }}$} & \multicolumn{5}{|c|}{ százalékos gyakoriság (\%) } \\
\hline & 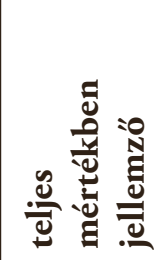 & 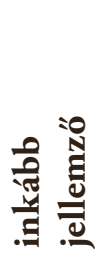 & 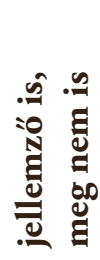 & 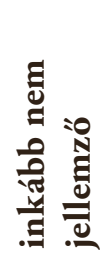 & 总 \\
\hline $\begin{array}{l}\text { szakmai kihívást jelentett } \\
\text { a pedagógusok számára }\end{array}$ & 32,8 & 47,2 & 16,8 & 3,2 & 0 \\
\hline $\begin{array}{l}\text { motiváló hatás az iskolai } \\
\text { munkára }\end{array}$ & 20,8 & 41,6 & 28 & 8 & 1,6 \\
\hline $\begin{array}{l}\text { támogatta a pedagógusokat } \\
\text { az előmeneteli rendszerben }\end{array}$ & 24,8 & 35,2 & 28 & 9,6 & 2,4 \\
\hline $\begin{array}{l}\text { folyamatos túlterheltséget } \\
\text { jelentett a tantestület } \\
\text { számára }\end{array}$ & 12,8 & 40 & 30,4 & 13,6 & 3,2 \\
\hline $\begin{array}{l}\text { anyagi elismerést jelentett } \\
\text { a pedagógusoknak }\end{array}$ & 24 & 48,8 & 24,8 & 1,6 & 0,8 \\
\hline
\end{tabular}

8.15. táblázat: A pályázatok hatása a szakmai önfejlesztés szempontjából

\begin{tabular}{|l|c|}
\hline kategóriák $\mathbf{N}=\mathbf{1 0 2}$, nem válaszolt $\mathbf{5 9}$ & százalékos gyakoriság (\%) \\
\hline 5 éve vagy annál kevesebb & 16,6 \\
\hline 6-10 éve & 15,6 \\
\hline 11-15 éve & 10,7 \\
\hline 16-20 éve & 9,8 \\
\hline 21-25 éve & 8,8 \\
\hline 26-30 éve & 6,8 \\
\hline 31 vagy annál több éve & 4,9 \\
\hline
\end{tabular}

8.18. táblázat: Továbbképzések eloszlása az iskolában eltöltött évek vonatkozásában 


\begin{tabular}{|l|c|c|}
\hline & \multicolumn{2}{|c|}{$\begin{array}{c}\text { Ön tartott-e valamilyen továbbképzést } \\
\text { az elmúlt öt évben? }\end{array}$} \\
\hline kategóriák $\mathbf{N}=\mathbf{8 7}$ & $\begin{array}{c}\text { igen/százalékos } \\
\text { gyakoriság }(\%)\end{array}$ & $\begin{array}{c}\text { nem/százalékos } \\
\text { gyakoriság (\%) }\end{array}$ \\
\hline Barkóczy úton tanítók & 1 & 16 \\
\hline Bartók téren tanítók & 8 & 16 \\
\hline mindkét épületben tanítók & 25 & 33 \\
\hline
\end{tabular}

\subsection{9. táblázat: A továbbképzéseket tartott pedagógusok épületek szerinti megoszlása}

\begin{tabular}{|l|c|c|}
\hline $\begin{array}{l}\text { megtartott } \\
\text { továbbképzések témái }\end{array}$ & hány alkalom & óraszám \\
\hline IKT & 11 & 449 \\
\hline módszertan & 8 & 2079 \\
\hline $\begin{array}{l}\text { szakmai megújulás, } \\
\text { előmenetel }\end{array}$ & 3 & 105 \\
\hline környezeti nevelés & 3 & 66 \\
\hline tehetséggondozás & 2 & 6 \\
\hline kerettanterv, tankönyv & 1 & 10 \\
\hline érettségi követelmények & 1 & 30 \\
\hline múvészeti nevelés & 1 & 1 \\
\hline egyéni bánásmód & 1 & 20 \\
\hline sport & 1 & 4 \\
\hline képzők képzése & 1 & 30 \\
\hline gyakornok felkészítése & 1 & 10 \\
\hline mérés-értékelés & 1 & 1 \\
\hline
\end{tabular}

8.21. táblázat: A pedagógusok által megtartott továbbképzések 


\begin{tabular}{|l|c|}
\hline célcsoportok & alkalom \\
\hline pedagógusok általában & 19 \\
\hline középiskolai tanárok & 4 \\
\hline szakvezetokk & 4 \\
\hline szaktanárok & 3 \\
\hline általános iskolai tanárok & 2 \\
\hline külföldi tanárok & 1 \\
\hline intézményvezetők & 1 \\
\hline gyakornokok & 1 \\
\hline óvodapedagógusok & 1 \\
\hline összes & 36 \\
\hline
\end{tabular}

\subsection{2. táblázat: Továbbképzések különböző célcsoportoknak}

\begin{tabular}{|l|c|c|}
\hline $\begin{array}{l}\text { kategóriák } \\
\mathbf{N}=\mathbf{1 0 2}\end{array}$ & gyakoriság & $\begin{array}{c}\text { százalékos gyakoriság } \\
(\mathbf{\%})\end{array}$ \\
\hline igen, több kutatásba & 17 & 16,7 \\
\hline igen, egy kutatásba & 22 & 21,6 \\
\hline nem kapcsolódott be & 63 & 61,8 \\
\hline összes & 102 & 100 \\
\hline
\end{tabular}

8.25. táblázat: Pedagógusok, akik bekapcsolódtak valamilyen kutatásba

\begin{tabular}{|l|c|}
\hline kategóriák & elégedettség/átlag (\%) \\
\hline igen, több kutatásba bekapcsolódott & 25,02 \\
\hline igen, egy kutatásba bekapcsolódott & 20,02 \\
\hline
\end{tabular}

8.27. táblázat: A több vagy egy kutatásban részt vevő pedagógusok elégedettsége az egyetemi oktatókkal való együttmúködéssel 


\begin{tabular}{|l|c|}
\hline kategória $\mathbf{N}=\mathbf{1 2}$ & átlag \\
\hline tanár szakos hallgatók magas színvonalú felkészítése szaktárgyuk tanítására & 5 \\
\hline kimagasló szakmai színvonalú oktatás & 4,83 \\
\hline a pedagógusok folyamatos szakmai fejlesztése & 4,75 \\
\hline lemaradók felzárkóztatása & 4,75 \\
\hline példamutatás más iskoláknak & 4,67 \\
\hline a szülőkkel való szoros partneri együttműködés & 4,33 \\
\hline pedagógusok szaktudományos képzése & 4,25 \\
\hline a diákok felkészítése a felsőoktatási továbbtanulásra & 4,25 \\
\hline szilárd erkölcsi értékek & 4,17 \\
\hline a pedagógusok szakmai karrierjének támogatása & 4,08 \\
\hline pedagógiai fejlesztések, innovációk innovációja & 4,08 \\
\hline kutatási együttműködés az egyetemmel & 3,92 \\
\hline sokszínű szabadidős tevékenység felkínálása & 3,92 \\
\hline pedagógiai fejlesztések, innovációk tervezése és megvalósítása & 3,83 \\
\hline szaktudományos tudás kialakítása & 3,83 \\
\hline a legjobb képességű diákok képzése & 3,75 \\
\hline tanulmányi versenyeken való részvétel & 3,58 \\
\hline pedagógusok részvétele pedagógiai és pszichológiai témájú kutatásokban & 3,5 \\
\hline a diákok motiválása kutatómunkára & 3,5 \\
\hline pedagógusok részvétele tudományterületi kutatásokban & 3,25 \\
\hline nemzetközi szakmai együttműködés & 3,25 \\
\hline
\end{tabular}

\subsection{8. táblázat: Az egyetemi oktatók által fontosnak tartott gyakorlóiskolai feladatok}




\begin{tabular}{|l|c|}
\hline kategória $\mathbf{N}=\mathbf{1 1}$ & átlag \\
\hline a tanárjelöltek óráinak az elemzése & 4,45 \\
\hline a tanárjelöltek szakmai fejlödésének értékelése & 4,36 \\
\hline a tanárjelöltek szakmai fejlödésének támogatása & 4,27 \\
\hline a tehetséges hallgatók támogatása & 4 \\
\hline pedagógusképzési tartalmak tervezése & 4 \\
\hline a tehetséges diákok támogatása & 4 \\
\hline a képzésekben való részvétel & 3,78 \\
\hline rendezvények tervezése & 3,78 \\
\hline különleges bánásmódot igénylő diákok támogatása & 3,78 \\
\hline rendezvényeken való részvétel & 3,75 \\
\hline pályázatok lebonyolítása & 3,67 \\
\hline képzések tervezése & 3,5 \\
\hline kutatásban, fejlesztésben való részvétel & 3,38 \\
\hline pályázatok tervezése & 3,33 \\
\hline különleges bánásmódot igénylö tanárjelöltek támogatása & 3,14 \\
\hline kutatások, fejlesztések tervezése & 3,13 \\
\hline publikációk készítése & 2,83 \\
\hline
\end{tabular}

8.29. táblázat: Az egyetemi oktatók elégedettsége a gyakorlóiskola pedagógusaival való együttmúködéssel

\begin{tabular}{|c|c|c|c|c|}
\hline $\mathbf{N}=22$ & 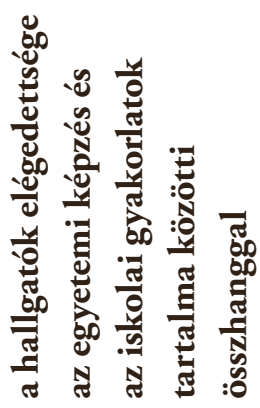 & 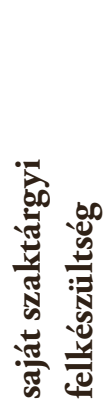 & 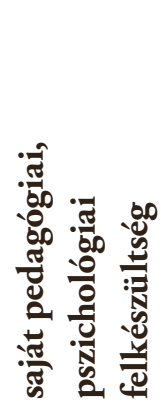 & 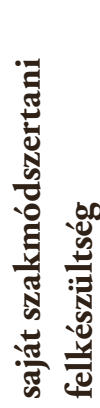 \\
\hline átlag & 2,89 & 4,05 & 4,11 & 3,94 \\
\hline
\end{tabular}

8.30. táblázat: A hallgatók elégedettsége az egyetemi képzés és az iskolai gyakorlatok tartalma közötti összhanggal 


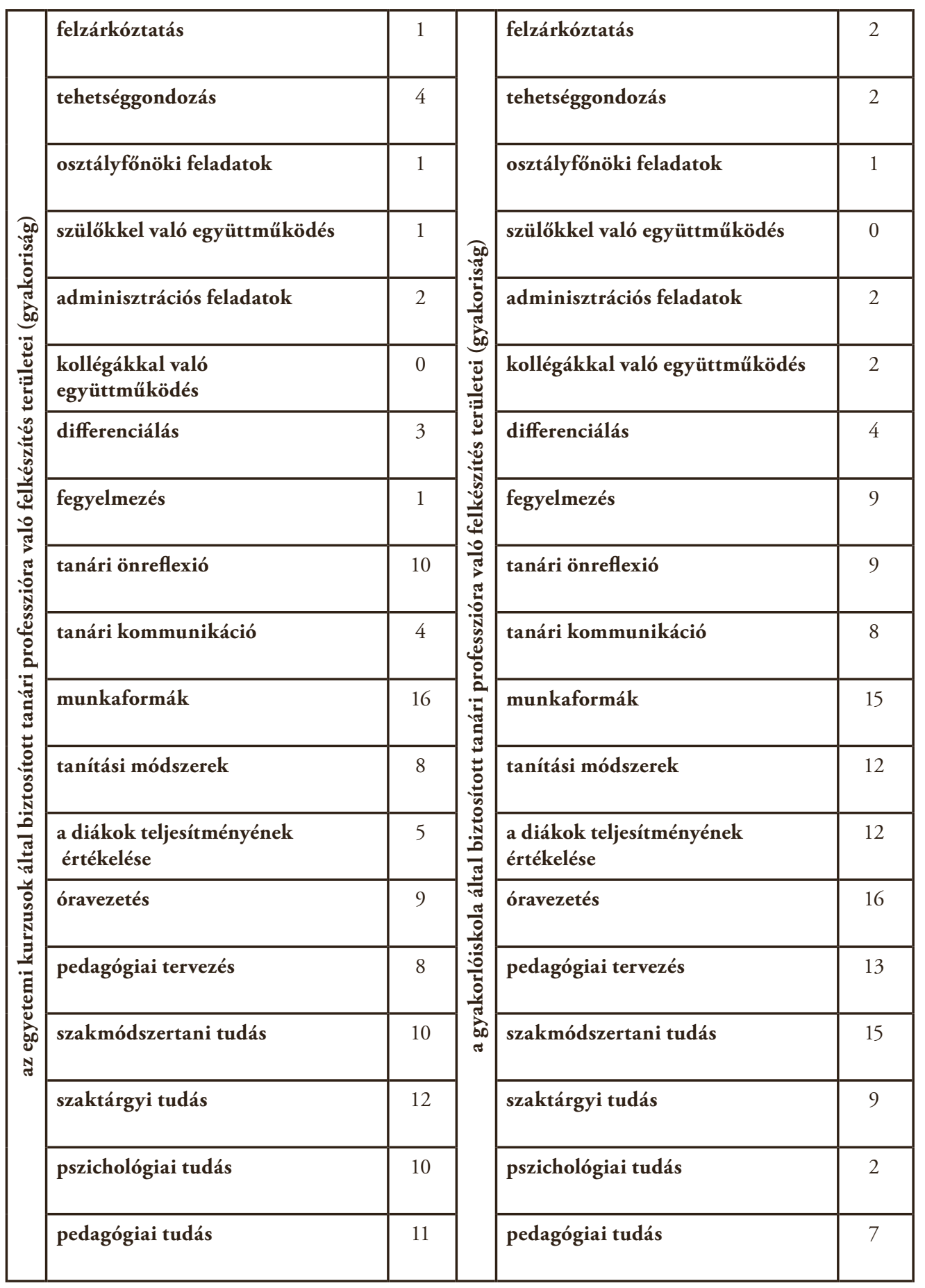

8.32. táblázat: A hallgatók elégedettsége az egyetemi kurzusok és a gyakorlóiskola által történő felkészítéssel 


\begin{tabular}{|l|c|c|}
\hline $\mathbf{N}=22$ & $\begin{array}{c}\text { tantestületi } \\
\text { értekezleteken való } \\
\text { részvétel az iskolai } \\
\text { gyakorlat során }\end{array}$ & $\begin{array}{c}\text { munkaközösségi } \\
\text { megbeszélésen való } \\
\text { részvétel az iskolai } \\
\text { gyakorlat során }\end{array}$ \\
\hline gyakoriság & 1 & 1 \\
\hline
\end{tabular}

8.33. táblázat: A hallgatók bevonása a tantestületi értekezletek és a munkaközösségek munkájába 